\title{
Bacterial Skin Infections in Livestock and Plant-Based Alternatives to Their Antibiotic Treatment
}

\author{
Lucie Mala ${ }^{1,2}$, Klara Lalouckova ${ }^{1,2}$ (D) and Eva Skrivanova $1,2, *$ (D) \\ 1 Department of Microbiology, Nutrition and Dietetics, Faculty of Agrobiology, Food and Natural Resources, \\ Czech University of Life Sciences Prague, Kamycka 129, 16500 Prague, Czech Republic; \\ malalucie@af.czu.cz (L.M.); lalouckova@af.czu.cz (K.L.) \\ 2 Department of Nutritional Physiology and Animal Product Quality, Institute of Animal Science, \\ Pratelstvi 815, 10400 Prague, Czech Republic \\ * Correspondence: skrivanovae@af.czu.cz
}

Citation: Mala, L.; Lalouckova, K.; Skrivanova, E. Bacterial Skin

Infections in Livestock and

Plant-Based Alternatives to Their Antibiotic Treatment. Animals 2021, 11, 2473. https://doi.org/10.3390/ ani11082473

Academic Editors: Luciana Rossi and Carlotta Giromini

Received: 12 July 2021

Accepted: 19 August 2021

Published: 23 August 2021

Publisher's Note: MDPI stays neutral with regard to jurisdictional claims in published maps and institutional affiliations.

Copyright: (C) 2021 by the authors. Licensee MDPI, Basel, Switzerland. This article is an open access article distributed under the terms and conditions of the Creative Commons Attribution (CC BY) license (https:/ / creativecommons.org/licenses/by/ $4.0 /)$.
Simple Summary: Bacterial skin infections in livestock are among the factors promoting antibiotic use. The use of antimicrobial agents has been shown to contribute to the increased prevalence of resistant bacterial strains. The rapid emergence and spread of resistant bacteria are a worldwide problem. With regard to the development of bacterial antibiotic resistance, phytochemicals are considered as possible substitutions of antimicrobial agents. In the field of plant-derived extracts, a number of studies deserve review because of the severity of the effects of resistant species of bacteria. This review presents current knowledge of plant-derived compounds, focusing on their modes of antibacterial action against pathogenic bacteria causing skin infections in livestock. Finally, great attention is given to specific plants that have antibacterial effects and are used in the healing and wound treatment of farm animals.

Abstract: Due to its large surface area, the skin is susceptible to various injuries, possibly accompanied by the entrance of infective agents into the body. Commensal organisms that constitute the skin microbiota play important roles in the orchestration of cutaneous homeostasis and immune competence. The opportunistic pathogen Staphylococcus aureus is present as part of the normal biota of the skin and mucous membranes in both humans and animals, but can cause disease when it invades the body either due to trauma or because of the impaired immune response of the host. Colonization of livestock skin by S. aureus is a precursor for majority of bacterial skin infections, which range from boils to sepsis, with the best-characterized being bovine mastitis. Antibiotic treatment of these infections can contribute to the promotion of resistant bacterial strains and even to multidrug resistance. The development of antibiotic resistance to currently available antibiotics is a worldwide problem. Considering the increasing ability of bacteria to effectively resist antibacterial agents, it is important to reduce the livestock consumption of antibiotics to preserve antibiotic effectiveness in the future. Plants are recognized as sources of various bioactive substances, including antibacterial activity towards clinically important microorganisms. This review provides an overview of the current knowledge on the major groups of phytochemicals with antibacterial activity and their modes of action. It also provides a list of currently known and used plant species aimed at treating or preventing bacterial skin infections in livestock.

Keywords: wounds; Staphylococcus aureus; antibiotic resistance; phytochemicals

\section{Introduction}

The skin is the largest organ of animal and human bodies, is the outermost and first line of defense against infectious agents and is easily exposed to physical and chemical agents and different pathogens that cause a wide variety of infections and wounds [1] Among its functions is the ability to protect the internal body from mechanical impacts and pressure, restriction of the influence of temperature changes, lowering the potential impact 
of microorganisms, limiting radiation effects and preventing the entrance of different chemicals into the body [2].

The skin is an ecosystem composed of diverse habitats with an abundance of folds, invaginations and specialized niches that support a wide range of microorganisms [3]. The microbiota of the skin is dependent on the specific body site and includes bacteria (e.g., Proteobacteria, Corynebacterium and Staphylococcus spp.), fungi (e.g., Malassezia) and viruses (e.g., Capripox) [1]. These microorganisms play important roles in the host defense against pathogens and in the development of the host immune system [1,4,5]. A healthy skin microbiota contributes to host fitness by occupying pathogen adhesion sites and producing pathogen inhibitors [1]. Staphylococcus aureus is a common pathogen that can cause both localized and systemic infections. Some bacteria, including Staphylococcus epidermis and Corynebacterium spp., can inhibit or reverse the growth of S. aureus [6]. Competitive interactions between beneficial and pathogenic skin microbes may, therefore, play roles in preventing disease in livestock [7]. In contrast to humans, the skin of livestock and other animals is mostly covered with dense fur or feathers. Thus, the microbial composition differs among species [8]. Body location, biological sex, age, geographic location, diet, captivity versus living in the wild, proximity to other animals, maternal transfer and disease states are also important influences on the microbial community structure in animals [9]. Previous studies have described the microbial composition in different skin regions, with Staphylococcus spp. and Corynebacterium spp. predominating in most areas, Propionibacterium spp. predominating in sebaceous areas and gram-negative $(\mathrm{G}-)$ organisms (such as Betaproteobacteria) colonizing dry skin areas, such as the forearm and leg $[8,10-12]$.

In veterinary medicine, skin infections are common clinical issues. Farm animals can be injured in several ways, e.g., during transport, being kicked or bitten by another animal or by striking against hard objects [13]. Breaches in the skin can lead to skin and soft tissue infections, such as folliculitis and furunculosis, and to life-threatening septicemia [14]. As described in Table 1, dermal wounds can be colonized by a mixture of aerobic (Staphylococcus spp. and Streptococcus spp.) and anaerobic (Corynebacterium spp. and Trueperella spp.) bacteria [15]. However, the vast majority of bacterial skin infections in animals involve the genus Staphylococcus [14].

Table 1. The most common bacterial pathogens in the diseased skin of livestock [14].

\begin{tabular}{ll}
\hline Species of Livestock & Bacterial Pathogens \\
\hline Cattle & $\begin{array}{l}\text { Actinomyces bovis, Bacteroides melaninogenicus, Staphylococcus aureus, } \\
\text { S. hyicus, Streptococcus dysgalactiae, Fusobacterium necrophorum, Moraxella } \\
\text { bovis, Trueperella pyogenes }\end{array}$ \\
\hline Pigs & $\begin{array}{l}\text { Dermatophylus congolensis, S. hyicus, S. intermedius, S. chromogenes, } \\
\text { S. sciuri }\end{array}$ \\
\hline Goats & $\begin{array}{l}\text { Dermatophylus congolensis, S. aureus, S. hyicus, S. haemolyticus, S. warneri, } \\
\text { S. epidermidis, S. chromogenes, S. caprae, S. simulans }\end{array}$ \\
\hline Sheep & $\begin{array}{l}\text { Dermatophylus congolensis, Corynebacterium pseudotuberculosis, } \\
\text { Pithomyces fungus, S. aureus, S. xylosus, S. epidermidis, Str. dysgalactiae }\end{array}$ \\
\hline Poultry & S. aureus, S. hyicus \\
\hline
\end{tabular}

In chronic wounds, some bacteria, such as Staphylococcus spp., Streptococcus spp. and Corynebacterium spp., are able to form biofilms, defined as a community of bacteria that have irreversibly attached themselves to a biotic or abiotic surface and secrete extracellular polymeric substances, resulting in higher antibiotic resistance and prevention of phagocytosis [16,17]. In most cases, a concentration of antibiotics in excess of 1000-fold is required to kill planktonic bacteria to destroy bacterial biofilms [16]. Biofilm organisms produce extracellular polymeric substances that facilitate attachment and matrix formation and encapsulate the entire assemblage, resulting in alterations in the phenotypes of the 
organisms and protection from antibiotics and the host immune system [18]. Furthermore, biofilm bacteria demonstrate a decreased growth rate, leaving them in a permanent growth state that is less susceptible to most antibiotics, which are typically designed to target rapidly dividing bacteria [16]. In veterinary and human medicine, the evolution of antibiotic-resistant genes and their spread among bacterial pathogens have important clinical significance [19].

In addition, antibiotic resistance becomes even more complicated with multidrugresistant bacteria, such as methicillin-resistant S. aureus (MRSA) [20]. Livestock have been identified as an emerging reservoir for the transmission of livestock-associated MRSA (LA-MRSA) to humans. LA-MRSA in humans was first detected in 2005 in a reservoir belonging to the CC398 lineage found in pigs and cattle [21]. Direct contact with live pigs is a known risk factor for LA-MRSA infection, and farm workers and veterinarians are more likely to be exposed and have a significantly elevated risk of becoming LA-MRSA carriers [22]. However, transmission of LA-MRSA is not restricted to persons in direct contact with infected animals, as members of their households show a higher level of LA-MRSA carriage compared to the general community [23]. Although CC398 is the main lineage associated with MRSA isolated from livestock, other clonal complexes and sequence types (STs) that are not within the CC398 variant have also been associated with livestock and animal products, including CC9 and CC130, which are both S. aureus clones commonly identified in animals [24]. In addition, other studies have reported the presence of LA-MRSA hybrids, specifically CC9/CC398, CC22, CC30, CC705, ST398 and ST425 hybrids. These isolates have been reported in dairy cows, cattle, pigs and poultry and in animal products [25-28].

Microbial resistance to antibiotics is constantly growing in both human and veterinary medical settings [29]. The aforementioned reasons clearly call for the development of alternatives to antibiotics. Among the studies on various antibiotic alternatives, the exploration of antibacterial properties of phytochemicals has resulted in successful outcomes. An overview of specific phytochemicals with antimicrobial effects and their relevance are described further in the following paragraphs.

\section{Staphylococcus aureus in Livestock}

Generally, staphylococci constitute a major group of bacteria inhabiting the skin, skin glands and mucous membranes of humans, other mammals and birds. Staphylococcus is a genus of gram-positive $(\mathrm{G}+)$ cocci-shaped bacteria in the family Staphylococcaceae that includes both coagulase-positive and coagulase-negative staphylococci [30]. Coagulase is an enzyme typically produced by S. aureus that causes blood clotting in the host, and its production has been accepted as the primary criterion for differentiating pathogenic species of staphylococci from commensal strains [31]. Coagulase-positive Staphylococcus species are clinically the most important opportunistic pathogens in many animals and can be considered a potential source of infection and dissemination to the environment [32].

S. aureus is an opportunistic pathogen of several animal species and was first recognized as an etiological agent more than 130 years ago. Animals with persistently colonized body sites (udder and teat skin, muzzle and vagina) represent the primary reservoirs of $S$. aureus and sources of infection for other animals and humans [14]. Overall, the ancient development of agriculture and the recent industrialization and globalization of the livestock industry have contributed to increased opportunities for the cross-species transfer of bacteria, and this spread has probably had a profound effect on the emergence of pathogens. The potential for transmission of $S$. aureus from animals to humans and vice versa is well known $[33,34]$. Transmission usually occurs by direct contact, often via the hands, with colonized or infected animals or people or with contaminated equipment and surfaces. The most common transmission pathways include the transfer from an infected mammary gland to an uninfected gland via fomites, such as milking equipment, or via the milker's hands, by uncontrolled animal trafficking between different farms and by handling or eating food contaminated with S. aureus [35]. Strict hygiene at the time of 
milking, segregation of any livestock with S. aureus infection and intensive culling of those infected might be required to reduce the prevalence and incidence of highly transmissible strains of the bacterium [36]. Thus, S. aureus has a huge impact on animal health and welfare and causes major economic losses in livestock production [34,37].

S. aureus is one of the three major pathogenic Staphylococcus species of animal skin, together with S. hyicus and S. intermedius [38]. S. aureus is found in healthy carriers and can induce a broad array of infections ranging from superficial skin diseases to deep infections and septicemia. Virtually any species of warm-blooded animal can be a healthy carrier or can be infected by $S$. aureus with the known manifestations of the infection [39]. Staphylococcal infections, particularly those caused by $S$. aureus, in farm animal species have been studied for many years, particularly with reference to bovine mastitis, which is defined as "inflammation of the mammary gland" [40]. The physical origins of infection have been identified as contagious, environmental or temporal, e.g., occurring during the dry period or lactation [41]. In addition to S. aureus, the coliform bacterium Escherichia coli and several streptococcal species, including Streptococcus uberis and Streptococcus agalactiae, are other major causes of mastitis [42]. E. coli is almost always taken up from an environmental source, while other pathogens, such as S. aureus and Str. agalactiae, are typically transmissible; in contrast, Str. uberis can usually act in both contagious and environmental forms. In this case, the crucial step of the identification is the diagnosis of the clinical mastitis and its patterns. Using such an approach may ensure appropriate and effective management interventions for the control of the disease at the herd level [43].

Folliculitis, furunculosis and impetigo are other common staphylococcal infections of the skin in livestock, especially in cattle, goats and sheep. Folliculitis- and furunculosisassociated livestock skin infections may be manifested by skin lesions in almost any location on the body [44]. In contrast to impetigo, where the hair follicle is not involved, the early lesions caused by staphylococci are follicular papules, which develop into a transient pustule with hairs emerging through the lesion. With progression, the condition may include focal crusting, leading to alopecia [14]. Another example of Staphylococcus spp.related skin disease in livestock is inflammation of the lower part of the foot in poultry and bumblefoot. These manifestations are often caused by injuries that allow contamination of the subcutaneous tissue in the footpad [45]. All of the aforementioned skin diseases are associated with the pathogenic bacterium S. aureus [14].

\section{Antibiotic Treatment of Bacterial Skin Infections in Livestock}

To improve and maintain animal health, antibiotics are applied in many cases. Decreasing the rate of bacterial infections influences not only animal health, but it also improves animal welfare and food safety, respectively [46]. Nevertheless, the use of antibiotics in animal production contributes to the increase of the burden of antimicrobial resistance in a global context [47]. Livestock is exposed to significant quantities of antibiotics, which also leads to their role as reservoirs of bacterial antimicrobial resistance genes. Moreover, animals can be a source of their transmission to humans via the food chain, direct contact and the environment [46].

Antibiotics are extensively used in livestock production systems worldwide (Figure 1) for disease treatment and in some countries for nontherapeutic purposes, such as growth promotion and disease prevention [48]. However, in 2006, the European Union (EU) banned the use of antibiotics for growth-promoting purposes. One of the main reasons for the adoption of the ban was the spread of antibiotic-resistant bacteria to humans [49]. In the EU, antimicrobial usage for therapeutic purposes is particularly high in intensively farmed species such as pigs and poultry and less in extensively farmed cattle (dairy cows are the exceptions) and sheep. In livestock, tetracyclines and penicillins are the most commonly used antimicrobial agents. In European countries, $31.7 \mathrm{mg} / \mathrm{PCU}$ (Population Correction Unit) of tetracyclines and $29.7 \mathrm{mg} / \mathrm{PCU}$ of penicillins were prescribed for use in veterinary medicine in 2018. The consumption of these substances was up to 30-fold higher than the consumption of other classes of antibiotics [48]. 




Figure 1. Sales of the various antimicrobial classes in $\mathrm{mg} / \mathrm{PCU}$ for use in livestock in 30 European countries in 2018.

In livestock, tetracyclines have been widely used for many decades to treat a variety of bacterial skin infections, including to treat multidrug-resistant pathogens such as MRSA [50]. Chlortetracycline and oxytetracycline are widely and successfully used for bovine pneumonia prophylaxis and treatment of calf and piglet scours, foot rot, metritis and acute mastitis, as well as for Pasteurella multocida infections in poultry [51].

$\beta$-Lactams, especially penicillins, are used to treat various conditions, including bovine mastitis, pneumonia in calves, metritis in cows and erysipelas in pigs [51,52]. Penicillin and its derivatives, including methicillin, have been used for the treatment of infections caused by S. aureus [53]. However, certain strains of S. aureus have developed resistance to these agents and are known as the important veterinary and zoonotic pathogen MRSA. These bacteria show drug resistance to a large number of antibiotics, such as methicillin, penicillin and macrolide antibiotics [20].

In addition to tetracyclines and $\beta$-lactams, frequently used antibacterial agent categories for the treatment of bacterial skin diseases in livestock are macrolides, aminoglycosides and fluoroquinolones, in addition to specific substances, e.g., florfenicol [52,54].

\section{Resistance of Staphylococcal Species to Antibiotics}

During recent decades, the continuing rapid development of bacterial resistance to antibiotics has emerged as a major global public health concern, especially with respect to $S$. aureus infection [55]. Bacterial antibiotic resistance occurs naturally over time, usually due to genetic modifications acquired through mutation and selection and/or gene acquisition between strains and species [56]. Resistance to antibiotics that are structurally similar to substances produced by soil bacteria and fungi is likely to have developed long before the clinical use of antibiotic agents in human and veterinary medicine [57]. The selective pressure imposed by the use of antimicrobial agents plays a key role in the emergence of resistant bacteria. Whenever a mixed bacterial population is exposed to antimicrobial agents, it is likely that certain bacteria in the population are resistant to the respective drugs at the concentrations applied. Under selective pressure, the number of these bacteria increases, and some may pass their resistance genes to other members of the population [56]. Generally, bacterial resistance can be classified as clinical and microbiological and, in turn, can be primary (intrinsic) or secondary (acquired). Bacteria can show intrinsic resistance as a result of their own structural characteristics, but can also acquire resistance via mutations of chromosomal genes and by horizontal gene transfer, i.e., the lateral movement of genetic information between organisms [58]. 
The development of antibiotic resistance by $S$. aureus was first reported in the mid1940s when a strain developed resistance to penicillin during the production of a hydrolyzing enzyme called penicillinase [59]. S. aureus is an adaptable organism with the ability to evolve and become resistant to a wide array of antibiotics [60], and as an opportunistic pathogen, $S$. aureus develops resistance to antimicrobials through different mechanisms. As described Figure 2, these mechanisms include limiting uptake of the drug, modification of the drug target, enzymatic inactivation of the drug and active efflux of the drug [61].

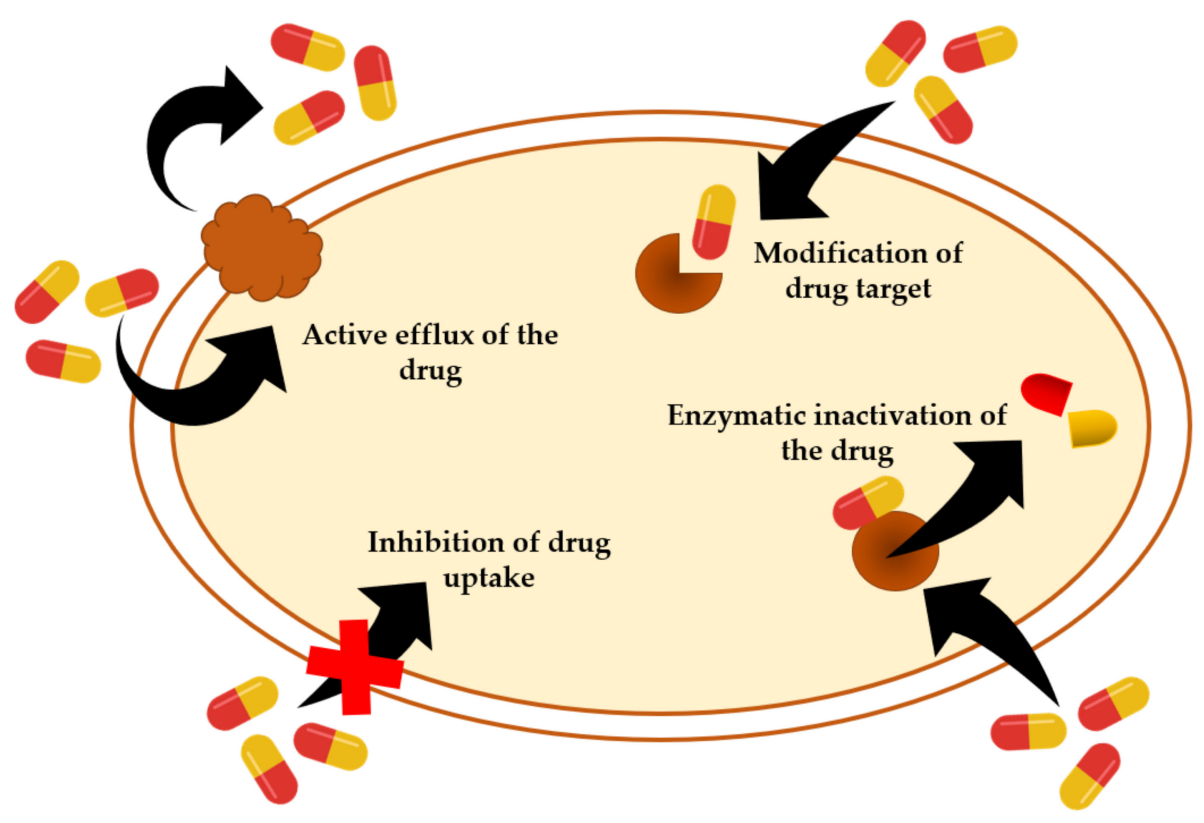

Figure 2. Antimicrobial resistant mechanisms of Staphylococcus aureus.

Depending on the antimicrobial involved, the bacteria may use one or several of the aforementioned resistance mechanisms. In particular, the localization of resistance genes on transferable genetic elements such as plasmids and transposons facilitate horizontal transfer of resistance between bacteria [61]. In general, $S$. aureus strains contain a relatively large variety of mobile genetic elements, including plasmids, transposons, bacteriophages, pathogenicity islands and staphylococcal cassette chromosomes. Plasmids and staphylococcal cassette chromosomes in particular have played central roles in conferring resistance to $\beta$-lactam antibiotics and vancomycin [62]. In addition, resistance of $S$. aureus is enhanced by the ability of the bacterium to form biofilms that provide protection from the host immune system and antibiotics. Additionally, bacteria in a biofilm state display increased resistance to a stress conditions compared to those in the planktonic state [63]. Growth of the bacteria in a biofilm play an important role during infection by providing a defense against several clearance mechanisms. Specifically, the biofilm matrix can impede the access of certain types of immune defenses, such as macrophages, which display incomplete penetration into the biofilm matrix and phagocytosis [64]. One suggested mechanism for this phenomenon is that the biofilm matrix blocks access to actively growing cells within the biofilm by decreasing antibiotic diffusion rates [65]. Moreover, S. aureus biofilms also play an important role in the progression of chronic diseases. Individual cells can disperse from the original biofilm and either seed new sights of infection or mediate an acute infection such as sepsis [66].

Staphylococcal infections have been usually treated with $\beta$-lactam antibiotics, but as MRSA strains have spread worldwide, different antibiotics, including vancomycin, daptomycin and linezolid, have been used. Nevertheless, antibiotic MRSA treatment may be challenged by the resistance to oxazolidinone (namely linezolid) and vancomycin [67]. Although the most commonly recommended drug for the treatment of MRSA infections is the glycopeptide vancomycin [68], in some S. aureus strains, vancomycin treatment 
failure started to be prevalent [69]. Three categories of S. aureus that are resistant to vancomycin and which have emerged in different locations of the world include vancomycinintermediate $S$. aureus (VISA), heterogeneous vancomycin-intermediate S. aureus (hVISA) and vancomycin-resistant S. aureus (VRSA) [70]. Previously, in vitro studies suggested the existence of various mechanisms for vancomycin resistance in MRSA, with the most prevalent one being the decreased permeability and the increased thickness of the cell wall, and hence, a decreased availability of vancomycin for intracellular target molecules. Another type of resistance is caused by plasmid-mediated vancomycin resistance genes, namely van $A$, vanB, vanD, vanE, vanF and van $G$, which are assumed to be transferred to $S$. aureus from enterococcal species $[71,72]$. However, vancomycin is not regularly used for the treatment of the diseased animals. In veterinary medicine, there are only few reports of vancomycin-resistant S. aureus [73].

\section{Alternatives to Conventional Antibiotics Used to Treat Bacterial Skin Infections in Animals}

The problem of antibiotic resistance has been known for decades but has accelerated in recent years [55]. The increase in prevalence of worldwide bacterial resistance to antibiotics requires the development of new antibacterial alternatives. First of all, biosecurity is the most important for preventing the spread of several contagious livestock diseases [74]. In addition, there are a number of antibacterial and immunity boosting compounds used in livestock, such as probiotics and prebiotics [75], synbiotics [76], organic acids [75] and clay minerals [77], but also feed enzymes and phytogenic additives [78]. Antimicrobial peptides, vaccines or bacteriophages can also be used for prevention or treatment of various invasive diseases [79]. Regarding bacterial skin infections in animals, phage therapy is commonly used in bovine mastitis [80] and in chronic wounds of swine [81]. Moreover, there are alternatives to antibiotics with topical use in the form of immunomodulators, which are already used in relation to prevent bovine mastitis [82], or in the form of metal-based antimicrobials, such as copper or zinc. However, in relation to heavy metals, further studies are needed to consider possible toxicity to the animal organism [83].

In traditional medicine, whole plants or mixtures of plants are used rather than isolated compounds [84]. Regarding high antimicrobial activity, pure drugs that are industrially produced or isolated from plants may be chosen for the treatment of bacterial diseases. However, their disadvantage is the lower degree of activity compared to the crude extracts at the comparable concentrations or dose of the active component [85]. Moreover, pure drugs are often more expensive to produce and distribute, and thus, they are often unavailable and/or unaffordable to some parts of the population [86]. In the case of crude extracts, these are complex of hundreds or even thousands of individual constituents which may have increased antibacterial activity due to synergistic action, or conversely lower activity due to the antagonistic action, of the substances with one another [85]. Therefore, research is increasingly focused on the antibacterial potential of these substances [87].

Nature is undoubtedly the richest source of molecules with the most varied biological features. Due to the biodiversity not only between animal and plant kingdoms but also among various species, nature represents the largest library of compounds that has ever existed [88]. Evidence of the use of plants for medicinal purposes dates as far back as 60,000 years ago in both Western and Eastern cultures [89]. Plants serve as useful sources of antimicrobial drugs and offer potential compounds for the development of new antibacterial agents [90]. Regarding antimicrobial action, promising compounds extracted from plants include alkaloids, polyphenols, saponins, tannins, terpenoids, glucosinolates and sulfides [91,92]. Moreover, lectins, together with polyacetylenes, can have the same antimicrobial activity as the aforementioned substances [93].

\section{Phytochemicals}

Phytochemicals are biologically active, plant-derived chemical substances that were traditionally used for medicinal purposes, giving them great therapeutic potential [94]. In ethnoveterinary medicine, parts of plants, such as roots, bark, stems, leaves, flowers and 
seeds, are used in the form of infusions, decoctions, ointments, powders and drops [95]. Phytochemicals have a wide activity range, according to the associated plant species, topography and climate of the country of origin and may exert different types of effects [94]. The beneficial activity can be attributed to the content of saponins, terpenoids, phenolic compounds, alkaloids and carotenoids in the plant. In addition to their antioxidant, anthelmintic or other beneficial actions, phytochemicals may also have negative impacts, such as hepatotoxic and neurotoxic effects [96]. The exact classification of phytochemicals has not been performed thus far because of their wide variety. In recent years, phytochemicals have been classified as primary or secondary constituents, depending on their roles in plant metabolism [95]. Primary constituents include common sugars, amino acids, proteins and purines and pyrimidines of nucleic acids. Secondary constituents are the remaining plant chemicals, such as alkaloids, terpenes, flavonoids, plant steroids, lignans, saponins, phenolics and glucosides [97]. The basic classification of phytochemicals, together with their main effects, is summarized in Table 2.

Table 2. Classification of phytochemicals and their main effects.

\begin{tabular}{|c|c|c|}
\hline References & Phytochemicals & Activity \\
\hline [92] & Alkaloids & Antimicrobial, anti-inflammatory \\
\hline [91] & Polyphenols & $\begin{array}{l}\text { Anticarcinogenic, antimicrobial, antioxidative, } \\
\text { antithrombic, immunomodulatory properties, } \\
\text { anti-inflammatory, influence on blood pressure }\end{array}$ \\
\hline [91] & Saponins & $\begin{array}{l}\text { Anticarcinogenic, antimicrobial, } \\
\text { immunomodulatory properties, influence on blood } \\
\text { pressure }\end{array}$ \\
\hline [92] & Tannins & Antimicrobial, anti-inflammatory, antioxidative \\
\hline [98] & Essential oils & Antimicrobial, anti-inflammatory \\
\hline [91] & Terpenoids & $\begin{array}{l}\text { Anticarcinogenic, antimicrobial, anti-inflammatory, } \\
\text { cholesterol-lowering effect }\end{array}$ \\
\hline [91] & Carotenoids & $\begin{array}{l}\text { Anticarcinogenic, antioxidative, immunomodulatory } \\
\text { properties, cholesterol-lowering effect }\end{array}$ \\
\hline [91] & Organosulfur compounds & $\begin{array}{l}\text { Anticarcinogenic, antimicrobial, antioxidative, } \\
\text { antithrombic, immunomodulatory properties, } \\
\text { anti-inflammatory, influence on blood pressure }\end{array}$ \\
\hline [91] & Phytosterols & Anticarcinogenic, cholesterol-lowering effect \\
\hline [91] & Protease inhibitors & $\begin{array}{l}\text { Anticarcinogenic, antioxidative, modulate blood } \\
\text { glucose levels }\end{array}$ \\
\hline [91] & Phytoestrogens & $\begin{array}{l}\text { Anticarcinogenic, antioxidative, immunomodulatory } \\
\text { properties }\end{array}$ \\
\hline
\end{tabular}

Contrary to the beneficial effects, an adverse event when using phytochemicals can be their toxicity. Both effective and toxic concentrations can be almost equal, subsequently interfering with the use of such a substance. In both human and veterinary medicine, an emphasis must be given to toxicity levels testing to prevent the use of lethal or sublethal doses [99].

Phytochemicals with Antimicrobial Effects

Alkaloids

Many definitions of alkaloids can be found in the literature, but generally, all include the statement that alkaloids are naturally occurring, low-molecular-weight organic substances with nitrogen-containing bases, most often produced by plants $[100,101]$. Although there is no fundamental taxonomic classification, alkaloids are usually classified based on their chemical structure, biochemical activity or natural origin [102]. From a biosynthetic 
point of view, alkaloids are derived from amino acids, such as phenylalanine, tyrosine, tryptophan, ornithine and lysine [103]. Based on their origin, three main categories exist: true-, proto- and pseudoalkaloids [102]. With regard to the biogenesis of alkaloids, they can be categorized into different classes according to their precursor (e.g., the largest group of alkaloids, indole alkaloids, are derived from tryptophan), thereby encompassing more than 20 different classes, such as pyrrolizidine alkaloids, tropane alkaloids, pyridine alkaloids, piperidine alkaloids, quinolizidine alkaloids, steroidal alkaloids and others [101,103].

Many alkaloids have important medical uses, whereas others are very toxic to both humans and animals [100]. Alkaloids usually have various potent biological activities and have a bitter taste [101]. Plants from the Papaveraceae and Berberidaceae families produce alkaloids with potential beneficial effects on wound healing. Both plant families produce isoquinoline alkaloids, which exert a range of biochemical effects relevant for medical use, such as alleviation of pain, inhibition of cancer cell growth and inhibition of bacterial growth [104]. To date, different studies have investigated the antimicrobial activity of some Papaveraceae species. The extracts of four annual poppy species showed strong antibacterial activity against the pathogen $S$. aureus [105]. The same study suggested that Papaver rhoeas extracts exhibited high inhibitory effects towards S. aureus, E. coli, Pseudomonas aeruginosa, Salmonella abony and Candida albicans pathogens [106]. In another study, strong antimicrobial activity of extracts from alkaloids in the Papaveraceae family was observed against both G+ and G- bacteria [107,108]. Table 3 lists selected alkaloids and their minimum inhibitory concentrations (MICs) against bacteria.

Table 3. The minimum inhibitory concentrations of selected alkaloids against gram-positive and gram-negative bacteria.

\begin{tabular}{llllc}
\hline \multirow{2}{*}{ References } & & Alkaloids & \multicolumn{2}{c}{ MIC ( $\mu \mathrm{g} / \mathrm{mL})$} \\
\cline { 2 - 5 }$[109-111]$ & Classes of Alkaloids & Specific Representatives & G+ & G- \\
\hline \multirow{2}{*}[112-115]{} & Quinolines alkaloids & $\begin{array}{l}\text { 4-methyl quinolone, 8-hydroxyquinolone, } \\
\text { evocarpine }\end{array}$ & $2-50$ & $8-100$ \\
\hline$[116]$ & $\begin{array}{l}\text { Isoquinolines, aporphines, } \\
\text { phenanthrenes }\end{array}$ & $\begin{array}{l}\text { Lysicamine, artabotrine, liridine, } \\
\text { sanguinarine, berberine, jatrorhizine, } \\
\text { columbamine, buesgenine, palmitine }\end{array}$ & $0.5-2.5$ & $0.78-32$ \\
\hline
\end{tabular}

MIC: minimum inhibitory concentration; G+: gram-positive bacteria; $\mathrm{G}-:$ gram-negative bacteria.

According to the Clinical and Laboratory Standards Institute (CLSI) [117], penicillin, a $\beta$-lactam antibiotic, shows MICs similar to alkaloids against $\mathrm{G}+$ bacteria, specifically S. aureus ATCC 29213 (MIC 0.25-2 $\mu \mathrm{g} / \mathrm{mL}$ ) and Enterococcus faecalis ATCC 29212 (MIC $1-4 \mu \mathrm{g} / \mathrm{mL}$ ). However, some antimicrobial agents show lower MICs against these bacterial species, primarily towards $S$. aureus. These antibiotics include clindamycin and fusidic acid (both with a MIC of $0.06-0.25 \mu \mathrm{g} / \mathrm{mL}$ ). The MICs of these conventional antibiotics against $\mathrm{G}-$ pathogens are not included in CLSI tables. Based on the MIC values presented in Table 3, it is obvious that alkaloids show higher antibacterial activity against $\mathrm{G}+$ bacteria than against $\mathrm{G}-$ bacteria. This can be explained by the fact that the outer membrane of $\mathrm{G}-$ bacteria disables the penetration of numerous antibiotics, and the periplasmic space contains enzymes that can degrade exogenous molecules [118].

Generally, antibacterial mechanisms of action are not equal within alkaloid classes. Synthetic quinolone alkaloids may have respiratory inhibition effects, while isoquinolines, such as berberine, protoberberine, sanguinarine and benzophenanthridine, inhibit cell division by perturbing the Z-ring. Ungeremine, a phenanthridine isoquinoline alkaloid, acts by blocking nucleic acid synthesis. Finally, pergularinine and tylophorinidine, which are indolizidine alkaloids, inhibit nucleic acid synthesis by targeting dihydrofolate reductase [119].

Antibacterial activity is also influenced by structural relationships. Iwasa et al. [120] examined quaternary protoberberine alkaloids and revealed that growth inhibitory activity 
was influenced more by the type of oxygen substituents on rings A, C and D and particularly by the position of the oxygen functional groups on the ring. Azimi et al. [115] also observed similar results, and four tested alkaloids showed potent antibacterial activity towards Brucella abortus. However, jatrorrhizine and columbamine, which have a free hydroxyl group on C-2 or C-3, showed stronger activity than berberine and palmatine, which have no free hydroxyl groups.

With regard to the antibacterial activity, synergistic and antagonistic effects of alkaloids in combination with antimicrobial drugs were observed. Sanguinarine, a benzophenanthridine alkaloid, has strong antibacterial activity against $\mathrm{G}+$ bacteria. In addition, this agent shows synergistic activity with streptomycin and a chelating agent, ethylenediaminetetraacetic acid (EDTA). Tong et al. [121] found a synergistic effect of berberine with $\beta$-lactam antibiotics against MRSA.

In contrast to their benefits, some alkaloids may have a toxic effect on both the animal and human body. In livestock, many species of lupines contain quinolizidine or piperidine alkaloids known to possess toxic or teratogenic effect [122]. Norditerpenoid alkaloids act as antagonists blocking the ligand binding sites of nicotinic acetylcholine receptor and causing acute toxicosis in adult animals that can result in death. Additionally, steroid alkaloids from Veratrum californicum such as cyclopamine inhibit the hedgehog signaling pathway, which disrupts embryonic development, causing developmental defects [123].

\section{Polyphenols}

Polyphenols are secondary metabolites ubiquitously distributed in all higher plants. The chemical structures of polyphenols comprise a wide variety of molecules and are generally classified into flavonoids and nonflavonoids [124]. Flavonoids constitute the largest class of polyphenolic compounds, with more than 4,000 structurally unique flavonoids already identified in various plant sources, such as vegetables, fruits and plant-derived beverages (e.g., tea and wine) [125]. Depending on the oxidation state of the central pyran ring, flavonoids can themselves be subdivided into many subclasses: flavonols, flavones, flavanones, anthocyanidins, flavanols and isoflavones. Nonflavonoids include simple phenols, phenolic acids, phenolic amino acids, curcuminoids, stilbenes, lignans and hydrolysable gallotannins and ellagitannins [124].

Generally, polyphenols have strong antibacterial activity against G+ (e.g., S. aureus, Streptococcus mutans, Clostridium perfringens) and G- (e.g., E. coli) bacteria, probably due to different mechanisms of action, among which the most convincing identified involves the aggregatory effect on all bacterial cells $[124,126]$. However, nonflavonoids show weaker antimicrobial activity than flavonoids [127]. Table 4 lists the selected flavonoids and nonflavonoids and their MICs against bacteria.

Table 4. The minimum inhibitory concentrations of selected phenolic compounds against gram-positive and gramnegative bacteria.

\begin{tabular}{|c|c|c|c|c|}
\hline \multirow{2}{*}{ References } & \multicolumn{2}{|r|}{ Phenolic Compounds } & \multicolumn{2}{|c|}{$\operatorname{MIC}(\mu \mathrm{g} / \mathrm{mL})$} \\
\hline & Classes of Phenolics & Specific Representatives & $\mathrm{G}+$ & $\mathrm{G}-$ \\
\hline [128-132] & Flavonoids & $\begin{array}{l}\text { Quercetin, myricetin, brazilin, } \\
\text { neobavaisoflavonde, lupinifolin, } \\
\text { 6,8-diprenyleriodictyol, pseudarflavone A }\end{array}$ & $0.5-62.5$ & $4-32$ \\
\hline [128-132] & Nonflavonoids & $\begin{array}{l}\text { 3'-demethoxy-6-O-demethylisoguaiacin, } \\
\text { 4-epi-larreatricin, dihydroguaiaretic acid, } \\
\text { resveratrol }\end{array}$ & $12.5->1000$ & $25-1280$ \\
\hline
\end{tabular}

MIC: minimum inhibitory concentration; G+: gram-positive bacteria; G-: gram-negative bacteria.

With regard to the values of the MICs of flavonoids and nonflavonoids in Table 4, the majority of these compounds were found to be more active against pathogenic bacteria, such as S. aureus, Listeria monocytogenes and E. coli, than conventional antibiotics, 
such as aminoglycosides (range of MICs $0.12-1 \mu \mathrm{g} / \mathrm{mL}$ ) and tetracyclines (range of MICs $0.12-4 \mu \mathrm{g} / \mathrm{mL}$ ) $[117,127]$. For this reason, they seem to be a suitable natural alternative towards bacterial pathogens. As reported above, flavonoids are more effective compared to nonflavonoids. This can be explained by the basic structural difference between these classes. Specifically, nonflavonoids contain only one phenol ring and flavonoids contain two phenol rings. Furthermore, the two phenol rings of flavonoids are connected via an oxygen-containing central pyran ring [133].

In phenolic compounds, multiple mechanisms of antibacterial activity have been described. One of these activities involves the interaction of polyphenols with bacterial proteins and cell wall structures [124,126]. The interactions of bacterial cell membranes with active hydroxyl groups of phenolic compounds cause either the disruption of the membrane structure, which induces a loss of cellular content, or the delocalization of electrons, which results in depolarization of bacteria, and thus, affects the proton motive force, reducing the $\mathrm{pH}$ gradient across the membrane and the level of the ATP pool [134]. Furthermore, phenolic compounds may inhibit nucleic acid synthesis or cell wall synthesis. The -OH groups of phenolic compounds interact with the cell membrane of bacteria by hydrogen bonding. Importantly, the presence of $-\mathrm{OH}$ functional groups is relevant to the antibacterial activity of many phenolics [135]. Moreover, longer aliphatic chain causes stronger hydrophobic properties of the compound, and can possibly enhance the antibacterial effect by enabling the substance to better interact with cytoplasmic membrane [136].

On the other hand, research on the anti-biofilm activity of plant phenolic compounds has revealed that in addition to their destructive effect on bacteria, their "softer" activity leads to biofilm suppression by affecting bacterial regulatory mechanisms, such as quorum sensing and/or other global regulatory systems, without exerting an effect on bacterial growth [137]. Recently published studies have confirmed the anti-biofilm activities of phenolic compounds, especially flavonoids, phenolic acids and tannins. The effects of these phenolic compounds were observed against both G+ and G- biofilm-forming bacteria [138-140]. For example, the flavonoids apigenin and quercetin have broad antibiofilm activity against $S$. aureus, E. coli and Str. mutans $[138,141]$. Coumarins, esculin, psoralen and nodakenetin have the same effect on P. aeruginosa [142]. Inhibition of biofilm formation by phenolic compounds may be crucial in future applications that prevent medical device biofilm-associated infections both in animals and humans [139].

The synergistic effect of polyphenols in combination with conventional antimicrobial agents against clinical multidrug-resistant bacteria was observed in most studies. The in vitro effect of two flavonols, especially kaempferol and quercetin, in combination with rifampicin (a complex macrocyclic antibiotic), was demonstrated towards MRSA isolates. Regarding the mechanism of action, use of these phytochemicals alone showed slight $\beta$-lactamase inhibition, but when combined with rifampicin, the complex exhibited good $\beta$-lactamase inhibitory effects [143]. Tea polyphenols have also been particularly proven to synergistically enhance the antimicrobial activity of antimicrobial agents used against MRSA [144].

However, the potential toxicity of some polyphenols in higher concentrations was also reported, such as catechin to damage DNA in mice spleen cells [145]. Moreover, notable negative effects were observed in fibroblast and keratinocyte cell lines after exposure to a high concentration of epicatechin for $24 \mathrm{~h}$ or longer [146]. The studies indicate that the positive effects could be obtained from polyphenols in a safe concentration range only [147].

\section{Tannins}

"Tannin" is a general descriptive name for a group of water-soluble polymeric phenolic substances, which differ from most other natural phenolic compounds in their ability to precipitate proteins such as gelatine from solution [148]. Tannins are found in abundance in tree bark, wood, fruit pods, leaves and roots and in plant galls. Tannins are subclassified into broad groups - proanthocyanidins (condensed tannins, CTs) and gallotannins and ellagitannins (hydrolysable tannins, HTs) [149]. HTs are generally multiple esters of 
gallic acid with glucose. Structurally, CTs are complexes of oligomers and polymers of flavonoid units (i.e., flavan-3-ols, flavan-3,4-diols and biflavans) linked by carbon-carbon bonds [150]. HTs are found primarily in fruit pods and plant galls, and in contrast to $\mathrm{CTs}$, their degradation products are absorbed by the small intestine of animals and are potentially toxic to ruminants [151].

Tannins inhibit the growth of diverse microbes, such as bacteria, fungi and yeasts [148]. Generally, the antimicrobial activity of tannins against $\mathrm{G}+$ bacteria has been reported to be greater than that against $\mathrm{G}-$ bacteria [152]. Table 5 shows a list of selected tannins and their MICs against bacteria.

Table 5. The minimum inhibitory concentrations of selected tannins against gram-positive and gram-negative bacteria.

\begin{tabular}{|c|c|c|c|c|}
\hline \multirow{2}{*}{ References } & \multicolumn{2}{|r|}{ Tannins } & \multicolumn{2}{|c|}{ MIC $(\mu \mathrm{g} / \mathrm{mL})$} \\
\hline & Classes of Tannins & Specific Representatives & $\mathrm{G}+$ & G- \\
\hline [153-155] & Gallotannins & $\begin{array}{l}\text { Tannic acid, hexa-O-galloylglucose, } \\
\text { hepta-O-galloylglucose, } \\
\text { 1,2,6-tri-O-galloyl- } \beta \text {-D-glucopyranose }\end{array}$ & $0.16-1000$ & $5-3200$ \\
\hline$[154,156,157]$ & Ellagitannins & $\begin{array}{l}\text { Punicalagin, corilagin, tellimagrandin I, } \\
\text { tercatain, chebulagic acid, isorugosin A, } \\
\text { davidiinm castalagin }\end{array}$ & $0.25-1000$ & $4-3200$ \\
\hline$[154,158,159]$ & Proanthocyanidins & $\begin{array}{l}\text { Procyanidin A1, procyanidin B1, procyanidin } \\
\text { B2, Procyanidin B3, procyanidin B4, rhodonidin } \\
\text { A, prodelphidin, epicatechin }\end{array}$ & $0.1-100$ & $2-800$ \\
\hline
\end{tabular}

MIC: minimum inhibitory concentration; G+: gram-positive bacteria; G-: gram-negative bacteria.

Based on the MIC values presented in Table 5, it is obvious that tannins and the abovementioned alkaloids have a greater antibacterial effect towards $\mathrm{G}+$ bacteria and a lesser antibacterial effect towards G- bacterial species. This pattern corresponds with facts previously mentioned in the subsection on alkaloids [118]. Because of the low MICs of selected tannins, such as tannic acid, tannins can be used as alternatives to antibiotics against pathogenic bacteria.

The mechanisms proposed thus far to explain tannin antimicrobial activity include inhibition of extracellular microbial enzymes, deprivation of the substrates required for microbial growth, direct action on microbial metabolism through inhibition of oxidative phosphorylation, metal ion deprivation or the formation of complexes with the cell membrane of bacteria causing morphological changes in the cell wall and increasing membrane permeability [148].

Gallotannins show higher antibacterial effects than ellagitannins. Tannic acid consisting of a central glucose and 10 galloyl groups had the lowest MIC value and is the most studied tannic acid with a broad spectrum of antibacterial activities [160]. Compared to proanthocyanidins, HTs show less pronounced antibacterial activities. Hydroxylation at positions 5 and 7 on the $B$ ring plays an important role in the antimicrobial effect of flavonols [161].

Tannins have been reported to show anti-biofilm effects. For example, tannic acid inhibited biofilm formation in the pathogenic bacteria S. aureus and E. coli $[162,163]$. In S. aureus, the anti-biofilm effect of tannic acid was mainly associated with the production of the protein "immunodominant staphylococcal antigen $\mathrm{A}$ ", which is a putative lytic transglycosylase that can cleave $\beta-1,4$-glycosidic bonds between the amino sugars of the bacterial cell wall, $\mathrm{N}$-acetylmuramic acid and $\mathrm{N}$-acetylglucosamine. Cleavage of the peptidoglycan layer can lead to a reduction in S. aureus biofilm thickness [164].

Although tannins are widely used due to their beneficial properties, the negative effects of tannins are also known. Tannin-containing plant can be less palatable due to the binding of tannin to salivary glycoproteins, resulting in an unpleasant taste [165]. Tannins also exhibit antinutritional properties by forming complexes with minor elements (such as 
calcium, magnesium or phosphorus), as well as with major elements (such as carbohydrates and proteins), rendering them unavailable for the utilization by the body. They may also form complexes with enzymes. High concentrations of tannins (up to $5.0 \mathrm{~g} / 100 \mathrm{~g}$ dry matter) may be toxic to the animal by causing irritation and desquamation of the intestinal mucosa, kidneys and lives lesions, ulcers and even death [166].

\section{Essential Oils}

As concentrated hydrophobic liquids, essential oils (EOs) are complex mixtures of volatile compounds produced by living organisms and isolated exclusively by physical means (pressing and distillation) from a whole plant or plant part of known taxonomic origin [167]. According to their chemical structure, these oils are alcohols, ethers or oxides, aldehydes, ketones, esters, amines, amides, phenols, heterocycles and mostly terpenes [168]. EOs and their constituents are known for their bioactive properties, including their antiseptic or antibacterial action $[135,169,170]$. Currently, the use of these phytochemicals to protect livestock from infections, mainly on organic farms, is becoming a common practice [171].

The activity of EOs is not equal, as they differ in their chemical structure. Some can also show synergisms [135]. The antimicrobial effect of EOs and their constituents has been explored in many in vitro assays, with variable results. The effect is highly dependent on the type of the compound, as well as on the bacterial type. Notably, Gbacteria are more tolerant to the action of essential oils than $\mathrm{G}+$ bacteria $[172,173]$. This finding can be attributed to the different structure of $\mathrm{G}-$ bacterial outer membrane and its limiting diffusion ability of hydrophobic compounds [174]. Moreover, the lipophilic ends of lipoteichoic acid in the cell membrane of $\mathrm{G}+$ bacteria may ease the infiltration of hydrophobic EO compounds [175]. An important attribute of EOs is their hydrophobic character, which can interfere with the membrane permeability [174]. This can then cause changes in ion channels $\left(\mathrm{Na}^{+}, \mathrm{K}^{+}, \mathrm{Ca}^{2+}\right.$ or $\left.\mathrm{Cl}^{-}\right)$and subsequent leakage of ions and other cellular molecules [175]. Even though a certain amount of leakage from bacterial cells can be tolerated without loss of viability, this phenomenon has its limitations. After the greater loss of cellular contents or critical output of molecules and ions, cell death is inevitable [176].

Generally, the chemical structure of EOs affects their antibacterial mode of action. EOs characterized by a high level of hydroxyl groups (i.e., thymol, eugenol, carvacrol and terpineol) are strongly reactive. This can lead to the interference with bacterial enzymes and their inactivation [177]. These compounds have high antimicrobial activity against pathogenic bacteria such as E. coli and Salmonella typhimurium, both of which are potential risk factors for enteric infections in livestock, especially in poultry. Moreover, the bacteria S. aureus, Bacillus cereus, L. monocytogenes, Campylobacter jejuni, Lactobacillus sake and Helicobacter pylori are susceptible to these EOs [98,178].

Some studies have concluded that whole EOs have greater antibacterial activity than mixtures consisting of major EO components $[179,180]$. This suggests that minor components in EOs are somewhat needed for EO inhibitory effect. They can have a synergistic effect or a potentiating influence [168]. Additive and synergistic effects of 1,8-cineole and aromadendrene against MRSA, vancomycin-resistant enterococci and $E$. faecalis have been reported [181]. Furthermore, Lambert et al. [169] observed an additive antimicrobial effect of carvacrol and thymol against $S$. aureus and P. aeruginosa. Oregano oil with gentamicin showed synergistic effects against $S$. aureus and Bacillus subtilis and B. cereus [182]. However, there are many EO components that have not been tested for determining their potential to enhance the efficacy of antibiotics [183].

Various studies have shown the toxicity of EOs in vitro and in vivo. EOs are commonly associated with hepatotoxicity, nephrotoxicity, changes in the blood vessels and oxidative stress that occur as a result of acute intoxication [184]. For example, a study focusing on the toxicity of an EO obtained from Syzygium aromaticum (containing mainly eugenol and caryophyllene) confirmed its negative effect on rats after intraperitoneal injection 
$(0.125 \mathrm{mg} / \mathrm{kg})$, resulting in changes of kidney tissue [185]. Some EOs have also been associated with toxicity to reproductive system. A recent study in rats demonstrated the prenatal toxicity of Verbena officinalis EO. Embryo-fetotoxicity was observed as evidence of the decrease in fetal weight, tail length and head cranium [186].

\section{Terpenoids}

Terpenoids, also referred to as terpenes, are the main constituents of EOs and constitute the largest group of natural compounds, accounting for more than 40,000 individual substances [187]. A majority of these compounds are abundant in flowers, fruits and vegetables. In particular, terpenes can be found at high concentrations in the reproductive structures and foliage of plants throughout and immediately following flowering [188]. Chemically, terpenes are usually cyclic unsaturated hydrocarbons with different degrees of oxygen in the constituent groups attached to the basic isoprene skeleton. The nomenclature of terpenoids depends on the number of isoprene structures and carbon atoms in the molecule; therefore, they are commonly classified as monoterpenes $\left(\mathrm{C}_{10}\right)$, sesquiterpenes $\left(C_{15}\right)$, diterpenes $\left(C_{20}\right)$, triterpenes $\left(C_{30}\right)$, tetraterpenes $\left(C_{40}\right)$ and polyterpenes $\left(C_{>40}\right)[189]$.

Terpenoids have several biological functions in higher plants. They are the key components of membrane structures, function as photosynthetic pigments and contain phytohormones (abscisic acid and gibberellins), and terpenoids known as ubiquinones are involved in mitochondrial electron transport [190]. Plant oils that included terpenes in their composition showed promising in vivo bactericidal activity, especially against various $\mathrm{G}+$ and G- pathogenic bacteria [191,192]. Table 6 lists selected terpenoids and their MICs against bacteria.

Table 6. The minimum inhibitory concentrations of selected terpenoids against gram-positive and gram-negative bacteria.

\begin{tabular}{lllcc}
\hline \multirow{2}{*}{ References } & & Terpenoids & \multicolumn{2}{c}{ MIC ( $\mu \mathrm{g} / \mathrm{mL})$} \\
\cline { 2 - 5 } & Classes of Terpenoids & Specific Representatives & G+ & G- \\
\hline$[193]$ & Monoterpenoids & $\begin{array}{l}\text { Carvacrol, thymol, linalool, citronellol, } \\
\alpha \text {-terpineol }\end{array}$ & $0.007-32$ & $0.015-55$ \\
\hline$[193]$ & Sesquiterpenoids & Xanthorrhizol, onopordopicrin & $0.5-86.2$ & $2.2-6.8$ \\
\hline \multirow{2}{*}[193]{} & Diterpenoids & $\begin{array}{l}\text { Carnosol, carnosic acid, rosmanol, } \\
\text { lasiodin, bafoudiosbulbin C, (-)-copalic } \\
\text { acid, dehydrobietic acid }\end{array}$ & $0.5-25$ & $3.1-64$ \\
\hline$[193]$ & Polyterpenoids & Nimbolide & 8 & - \\
\hline
\end{tabular}

MIC: minimum inhibitory concentration; G+: gram-positive bacteria; $\mathrm{G}-:$ gram-negative bacteria.

The MICs presented in Table 6 demonstrate that terpenoids are active against both G+ and G- bacteria. However, polyterpenoids, particularly nimbolide, show an MIC of $8 \mu \mathrm{g} / \mathrm{mL}$. This MIC indicates that some G+ bacteria are resistant to the effects of certain terpenoids. This resistance may be caused by a thick layer of peptidoglycan in the cell wall, which confers the cells with rigidity, making the passage of antimicrobial agents difficult [194].

Due to their lipophilic character, terpenes easily permeate through the cell wall and cell membrane. Disruption of membrane integrity and potential, leakage of cellular contents, denaturation of cytoplasmic proteins and inactivation of cellular enzymes lead to bacterial cell death [191]. Terpenoids also play key roles in the clinical industry [192].

Saponins

Saponins constitute a diverse group of bioorganic compounds that are widely distributed in the plant kingdom with a rigid skeleton of at least four hydrocarbon rings to which sugars in groups of one or two are attached [195]. Saponin phytochemical molecules consist of two key moieties, a hydrophilic sugar moiety and a lipophilic sapogenin moiety, the combination of which contributes to the characteristic soapy/detergent nature of 
saponins [196]. Based on the different types of sapogenin, there are two classes of saponins. One class consists of steroidal saponins, in which sapogenin contains the characteristic four-ringed steroid nucleus, with typical extra furan and pyran heterocyclic rings. Due to the lack of the extra rings, the ginsenosides in ginseng are considered to be the second class of saponins, known as the triterpenoid saponins, even though they exhibit a steroidal structure [197].

Due to their amphiphilic nature, saponins show a wide range of biological activities, such as cytotoxic, anticancer, insecticidal, molluscicidal, anti-inflammatory, antifungal, antiviral and antibacterial activities $[195,198]$. Regarding antimicrobial activity, this group of phytochemicals inhibits the growth of G+ and G- bacteria and yeasts and molds. For example, saponins from $Y u c c a$ exhibit antimicrobial activity against $\mathrm{G}+$ cells but do not act on G- bacteria [199]. However, Salvia officinalis extracts showed antibacterial effects against the G- pathogen E. coli. [200,201]. Table 7 lists selected saponins and their MICs against bacteria.

Table 7. The minimum inhibitory concentrations of selected saponins against gram-positive and gram-negative bacteria.

\begin{tabular}{|c|c|c|c|c|}
\hline \multirow{2}{*}{ References } & \multicolumn{2}{|r|}{ Saponins } & \multicolumn{2}{|c|}{$\operatorname{MIC}(\mu \mathrm{g} / \mathrm{mL})$} \\
\hline & Classes of Saponins & Specific Representatives & G+ & G- \\
\hline$[202,203]$ & Steroidal saponins & $\begin{array}{l}\text { Progenin II, diosgenin, spirosta-5,25(27)- } \\
\text { diene- } 1 \beta, 3 \beta \text {-diol-1-O- } \alpha \text {-l-rhamnopyranosyl- } \\
(1 \rightarrow 2)-\beta \text {-d-fucopyranoside (fruticoside } H \text { ) }\end{array}$ & $7.8->256$ & $128->256$ \\
\hline [204-206] & Triterpenoid saponins & $\begin{array}{l}\text { Oleanolic acid, betulinic acid, moronic acid, } \\
\text { ursolic acid, friedelane-3,11-dione }\end{array}$ & $1.52-64$ & $1-100$ \\
\hline
\end{tabular}

MIC: minimum inhibitory concentration; G+: gram-positive bacteria; $\mathrm{G}-$ : gram-negative bacteria.

The antibacterial mechanism of saponins against bacteria is not completely understood [207]. In general, the effect of saponins against bacteria is often weak [208]. It seems that saponins can interact with the bacterial outer membrane, increasing its permeability. There are inconsistent reports on the activity of glycosidic and aglycone forms of saponins. It was shown that bacterial enzymes could decrease the antibacterial effect of saponins through the hydrolysis of sugar chains [207]. Avato et al. [209] reported that the aglycone component of saponins had antibacterial activities and that the sugar chains are not critical for this activity, whereas Khan et al. [210] proved that the presence of sugar chains is important for the biological effects of the extracts. However, research conducted with $E$. coli demonstrated that oleanolic acid (OA), a known triterpenoid saponin, can also moderately affect efflux pumps, which can directly interfere with the viability of this bacterial species [211]. Other mechanisms of action of OA may be associated with the induction of a stress response [212]. Kurek et al. [213] verified that triterpenoid saponins inhibit peptidoglycan turnover in L. monocytogenes, affecting the amount of muropeptides and, ultimately, the cellular wall of bacteria, suggesting that this biochemical pathway can be a target for both triterpenes.

Regarding the antimicrobial effects, saponins also possess a significant antifungal activity. The mechanism of action involves pore formation and loss of membrane integrity. The mode of action is similar to the hemolytic activity of saponins [214]. A mechanism of action for the triterpene saponin of oats, (avenacin) was proposed. Briefly, it includes the administration of the aglycone fragments into the cell membrane, followed by binding to sterols. The next step comprises the interaction of sugar residues and the formation of sterol-saponin complexes. These complexes can lead to the restructuring of membrane lipids, the formation of pores and cell lysis [215].

Many studies have also investigated the synergistic effect resulting from the combination of antibiotics with saponins, discovering new ways to treat infectious diseases $[216,217]$. For example, a synergistic effect was observed for the glycoside of OA in combination with a tetracycline antibiotic against $S$. aureus and E. coli [217]. 
Negative effects of saponins are also known. Some of these substances have the ability to disrupt erythrocytes due to their interactions with the sterols [195]. For instance, the study of Yoshikawa et al. [218] confirmed the acute and sub-chronic toxicity of Camellia sasanqua seed saponins in mice. Tested mice showed severe gastrointestinal tract distension and submucosal changes in the small intestine, indicating that the toxic target could be the gastrointestinal system.

Organosulfur Compounds

Alliaceous vegetables are considered to be enriched within a large variety of beneficial substances, such as sulfur-containing compounds [219]. Organosulfur compounds are defined as organic molecules containing one or more carbon-sulfur bonds. These compounds are particularly prominent in the Alliaceae and Brassicaceae families of plants [220]. Organosulfur compounds in Allium and Brassica plants are called thiosulfinates and glucosinolates. These groups of phytochemicals are converted to various new sulfur-containing materials that exhibit a variety of bioactive properties via a number of biosynthetic reactions [221].

Thiosulfonates (TSFs) are the most studied compounds among the active constituents of Allium vegetables. Allicin, or diallyl thiosulfinate, is the main active substance of garlic (Allium sativum L., Amaryllidaceae). Injury to the tissue of the garlic wedge leads to the release of the enzyme alliinase, which produces allicin from the basic compound alliin [222]. Alliinase is characterized by both carbon and sulfur stereochemistry, although it occurs naturally as a racemate [223]. Allicin has broad low-level antimicrobial activity against G+ and G- bacteria, including against antibiotic-resistant bacterial strains and fungi [224].

Glucosinolates (GLSs) constitute a class of organic compounds that are formed from glucose and an amino acid and contain sulfur and nitrogen. Rich sources of these compounds are Brassica vegetables [225]. GLSs are present in plants with the enzyme myrosinase, which hydrolyses GLSs into active compounds, such as isothiocyanates, after tissue disruption. Isothiocyanates are the main active substances of GLSs and have strong antibacterial effects against both gram-positive and gram-negative bacteria [226].

Generally, organosulfur compounds-allicin, benzyl isothiocyanate, propyl-propane thiosulfonate and ajoene-showed high in vitro antibacterial activity. Allicin is the only compound from this group that was tested in animal models and clinical trials for the treatment of bacterial infections [227-229]. Table 8 lists the selected organosulfur compounds and their MICs against bacteria.

Table 8. The minimum inhibitory concentrations of selected organosulfur compounds against gram-positive and gramnegative bacteria.

\begin{tabular}{llllr}
\hline \multirow{2}{*}{ References } & \multicolumn{2}{c}{ Organosulfur Compounds } & \multicolumn{2}{c}{ MIC $(\mu \mathrm{g} / \mathrm{mL})$} \\
\cline { 2 - 6 } & Classes of Organosulfur Compounds & Specific Representatives & G+ & G- \\
\hline$[230-232]$ & Thiosulfinates & $\begin{array}{l}\text { Ajoene, Z-ajoene, allicin, propyl-propane } \\
\text { thiosulfinate }\end{array}$ & $4-20$ & $0.5->500$ \\
\hline$[233]$ & Glucosinolates & Benzyl-isothiocyanate, allyl-isothiocyanate & $4-40$ & $10-40$ \\
\hline
\end{tabular}

MIC: minimum inhibitory concentration; G+: gram-positive bacteria; G-: gram-negative bacteria.

TSFs, including allicin, use their -S(O)-S- group to inhibit bacterial growth. The group generally reacts with the $-\mathrm{SH}$ group of cellular proteins to generate mixed disulfides. The inhibitory action of TSFs is inactivated by sulfhydryl compounds such as cysteine [234]. All cysteine sulfoxides-derived antibacterial substances in alliums are believed to act via the equal mechanism, as their antimicrobial activities are inactivated by cysteine, except allyl alcohol [235]. The mechanism of allicin antimicrobial activity has been reported, which is due to the inhibition of sulfhydryl-dependent enzymes, including alcohol dehydrogenase, thioredoxin reductase and RNA polymerase [236]. Furthermore, allicin has been found to 
partially inhibit DNA and protein synthesis. The immediate effect of allicin on RNA has also been proven, which indicates the possibility that RNA is a target of allicin [237].

The mode of antibacterial action of GLSs is probably the inhibition of the activity of thiol groups in key bacterial enzymes or the blockade of electron transport and ATP synthesis [238]. The synergistic effect of TSFs and GLSs in combination with conventional antimicrobial agents against pathogenic bacteria was observed in most studies. For example, allicin shows synergistic and adjuvant activity with antibiotics such as oxacillin and cefazolin against $S$. aureus and P. aeruginosa [239]. Allicin- $\beta$-lactam combinations offer the promise of clinical utility, especially when synergism is demonstrated by in vivo experimental studies [240]. Additionally, isothiocyanates display synergy with conventional antibiotics. It was demonstrated that 2-(4-hydroxyphenyl)ethyl isothiocyanate had antimicrobial synergism with aminoglycosides such as streptomycin against $E$. coli and S. aureus [241]. However, small changes in the concentrations of both isothiocyanate and streptomycin affected their combined action, changing from synergism to the suppression of antimicrobial activity [242].

If organosulfur compounds are applied in a high concentration (up to $200 \mathrm{mg} / \mathrm{kg}$ of the body weight), an imbalance between chemical stress and response capacity leads to contradictory results along with adverse side effects, such as toxicity to the heart, brain, liver and other organs [243]. In the study of Alnaqeeb et al. [244], the intraperitoneal administration of garlic extract, in both low $(50 \mathrm{mg} / \mathrm{kg}$ of the body weight) and high doses (500 $\mathrm{mg} / \mathrm{kg}$ of the body weight), caused damage to the lung and liver in rats.

\section{Plants with Antibacterial and Wound Healing Effects Used in Livestock (In Vitro Studies)}

Many diseases affect livestock and other animals, and causal organisms of diseases include bacteria, viruses, protozoa, fungi and helminth parasites [245]. Plant phytochemical remedies are used for many livestock animals, including ovines, bovines, swine, poultry and rabbits. Prime disorders addressed by these substances comprise wounds and dermatological complications as well as gastrointestinal disorders and postnatal maladies [246]. It is essential to evaluate not only the bioactivity but also the safety of plant treatments when their use is to be promoted and potentially developed for commercial purposes. In vivo experiments are expensive and ethically complex; hence, many studies involve in vitro investigations of a particular bioactivity [245]. A number of in vitro experiments have been performed, in which plants were used for treating livestock bacterial skin diseases and in the healing process. Table 9 contains a list of these plants. 
Table 9. List of plants used to treat skin infections in livestock.

\begin{tabular}{|c|c|c|c|c|}
\hline References & Family & Botanical Name & Treatment & Part of Plant \\
\hline [247] & Altingiaceae & Liquidambar orientalis & Bovine mastitis & Leaves \\
\hline$[248,249]$ & Apiaceae & Eryngium planum, Conium maculatum, Sanicula europaea & Bovine mastitis, wound healing & Herb \\
\hline [251] & Asphodelaceae & Aloe species & Bacterial skin diseases, wound healing & Leaves \\
\hline [252] & Asparagaceae & Achyranthes aspera, Drimia maritima & $\begin{array}{l}\text { Bovine mastitis, other bacterial skin } \\
\text { diseases }\end{array}$ & Leaves \\
\hline
\end{tabular}

Achillea millefolium, Arnica montana, Artemisia nilagirica, Calendula officinalis, Eclipta

prostrata, Eupatorium triplinerve, Blumea lacera, Cyanthillium cinereum, Haplocarpha

[248,252-256] Asteraceae scaposa, Helianthus annuus, Matricaria recutita, Mikania scandens, Saussurea costus, Solidago virgaurea, Stevia rebaudiana, Tagetes erecta, T. patula, Tridax procumbens, Vernonia species, Wedelia chinensis

\begin{tabular}{|c|c|c|c|c|}
\hline [248] & Boraginaceae & Bourreria orbicularis, Heliotropium indicum, Symphitum officinale & Wound healing & Barks, leaves, roots \\
\hline [256] & Bignoniaceae & Spathodea campanulate & Bovine mastitis & Leaves \\
\hline [253] & Capparaceae & Capparis zeylanica & Wound healing & Leaves \\
\hline [250] & Clusiaceae & Garcinia mangostana & Bovine mastitis & Pericarp \\
\hline$[253,257]$ & Cucurbitaceae & Coccinia grandis & Bacterial skin diseases, wound healing & Fruits, leaves, roots \\
\hline$[253,258]$ & Dilleniaceae & Dillenia indica & Bacterial skin diseases, wound healing & Fruits \\
\hline [253] & Ebenaceae & Diospyros malabarica & Wound healing & Leaves \\
\hline$[248,252-256]$ & Euphorbiaceae & $\begin{array}{l}\text { Acalipha indica, Euphorbia hirta, Croton bonplandianum, C. macrostachyus, Jatropha } \\
\text { zeyheri, Ricinus communis }\end{array}$ & Wound healing & Leaves, roots \\
\hline
\end{tabular}
[248] Fabaceae corylifolium, Crocosmia aurea, Glycyrrhiza glabra, Pterocarpus marsupium, Rhynchosia capitate, Saraca indica, Senna alata, S. sophera, S. alexandria, Schotia latifolia, Vigna

Bovine mastitis, other bacterial skin diseases, wound healing

Fruits, leaves unguiculata

\begin{tabular}{|c|c|c|c|c|}
\hline [256] & Hypericaceae & Hypericum perforatum, H. revolutum & Wound healing & Flowers, roots \\
\hline [253] & Chenopodiaceae & Chenopodium bonus-henricus & Wound healing & Leaves \\
\hline [250] & Lamiaceae & $\begin{array}{l}\text { Anisomeles indica, Leucas aspera, Lavandula angustifolia, Mentha, arvensis, Minthostachys } \\
\text { verticillata, Ocimum sanctum, Ocimum tenuiflorum, Origanum vulgare, Plectranthus } \\
\text { amboinicus, P. ambiguous, Tectona grandis, Thymus vulgaris, Vitex negundo }\end{array}$ & $\begin{array}{l}\text { Bovine mastitis, other bacterial skin } \\
\text { diseases, wound healing }\end{array}$ & Flowers, leaves \\
\hline
\end{tabular}


Table 9. Cont.

\begin{tabular}{|c|c|c|c|c|}
\hline References & Family & Botanical Name & Treatment & Part of Plant \\
\hline$[253,257]$ & Lauraceae & Litsea glutinosa & Wound healing & Barks, leaves \\
\hline$[253,258]$ & Malvaceae & Gossypium herbaceium, Malva neglecta, M. sylvestris, Sida cordifolia & Bacterial skin diseases, wound healing & Herbs, leaves \\
\hline [253] & Menispermaceae & Tinospora sinensis & Wound healing & Stem \\
\hline$[248,252,253,256]$ & Molluginaceae & Glinus lotoides & Wound healing & Latex, leaves \\
\hline [248] & Moraceae & Ficus benghalensis, F. caria, F. racemosa, F.thonningi, Morus nigrai & Bacterial skin diseases, wound healing & Latex, leaves, roots \\
\hline [256] & Myrtaceae & Eucalyptus globulus, Syzygium cumini & Bacterial skin diseases & Leaves \\
\hline [253] & Papaveraceae & Fumaria indica, Papaver somniferum, Chelidonium majus & Bovine mastitis, wound healing & Leaves \\
\hline [250] & Pandaceae & Pandanus foetidus & Wound healing & Leaves \\
\hline$[253,257]$ & Pinaceae & Cedrus deodara, Picea abies & $\begin{array}{l}\text { Bovine mastitis, other bacterial skin } \\
\text { diseases }\end{array}$ & Bark \\
\hline$[253,258]$ & Poaceae & Bambusa bambos, Cynodon dactylon & Bovine mastitis, wound healing & Leaves, shoots \\
\hline [253] & Polygonaceae & Rumex obtusifolius & Bacterial skin diseases & Leaves, roots \\
\hline$[248,252-255]$ & Rhamnaceae & Ziziphus mucronata, Z. spina-christi & Bovine mastitis & Leaves, roots \\
\hline [256] & Salvadoraceae & Salvadora persica & Bacterial skin diseases, wound healing & Leaves \\
\hline [253] & Solanaceae & $\begin{array}{l}\text { Atropa belladonna, Datura metel, Nicotiana tabacum, Solanum hastifolium, S. } \\
\text { americanum, S. sodomeum, S. virginianum, Withania somnifera }\end{array}$ & $\begin{array}{l}\text { Bovine mastitis, other bacterial skin } \\
\text { diseases, wound healing }\end{array}$ & Leaves, roots \\
\hline [250] & Symplocaceae & Symplocos racemose & Bacterial skin diseases & Bark \\
\hline$[253,257]$ & Vitaceae & Cissus quandrangularis & Bacterial skin diseases & Aerial parts \\
\hline
\end{tabular}


In livestock, the plants most extensively used in the healing process and treatment of skin infections are in the Fabaceae and Asteraceae families.

\section{Plants with Antibacterial and Wound Healing Effects Used in Livestock (In Vivo Studies)}

Compared to in vitro studies, the number of in vivo studies of plant extracts is significantly lower. Current in vivo experiments of plant-derived compounds related to bacterial skin infections involve predominantly testing in rats (Sprague-Dawley and Wistar) [259] or in mice $[260,261]$, and to a lesser extent in rabbits [262]. Bibliographic research highlights a low number of in vivo experiments using livestock when evaluating the possible effect plants extracts in treating bacterial skin diseases. However, the antibacterial action of an herbal spray comprising of C. deodara, Curcuma longa, E. globulus and G. glabra has been assessed by Hase et al. [263] for its therapeutic effect on subclinical mastitis in bovines. Treatment by herbal spray achieved a $60 \%$ cure rate. Abboud et al. [264] studied the effect of $10 \%$ mixture of L. angustifolia and T. vulgaris in dairy cows, using it as an intramammary infusion or externally. After four days of treatment, it has been discovered that a substantial decrease in the bacterial colony count occurred. The most potent antimicrobial effect was achieved by massaging the udder with a mixture of EOs. In vivo activity of EOs was confirmed also in O. vulgare [265]. In addition, in vivo studies on skin diseases caused by mites were previously carried out. Kebede and Negese [266] tested the antimicrobial effect of E. globulus EO and Cymbopogon citratus EO in goats infected by Sarcoptes scabiei var. caprae. Animals were topically treated two times for 14 days interval and compared with non-treated and treated (diazone and ivermectin) controls. The infected goats treated with the EOs were cured completely.

\section{Conclusions}

Given the general concerns of the increased prevalence of antimicrobial resistance of microorganisms, especially S. aureus, the most common multidrug-resistant bacterium causing skin diseases in animals, there is an effort to limit the use of antibacterial agents to the lowest acceptable level. In livestock, staphylococcal bacterial infections are dangerous not only for their harmful effects on animal health but also for their potential for transmission from animals to humans and vice versa. Staphylococcal infections, therefore, have a huge impact on animal health and welfare and cause major economic losses in livestock production. In this regard, another problem is the treatment of staphylococcal infections, which requires antibiotic therapy. However, the administration of antibiotics to livestock can promote the development and spread of multidrug-resistant bacterial strains. The present review reports that plants are valuable sources of antibacterial compounds. Moreover, the combined therapy of selected phytochemicals with antibiotics can improve their pharmacokinetic and pharmacodynamic properties. Thus, phytochemicals open a wide range of possibilities for new antibacterial therapies in veterinary medicine. However, the use of plant substances may also have adverse effects on animals. The overall effect on the health status of animals may depend a great deal on the chemistry of the compounds, their concentration in the diet and the amount consumed. In this review, most of the cited studies were based on in vitro experiments; therefore, further detailed in vivo experiments are needed.

Author Contributions: Conceptualization, L.M.; resources, L.M.; writing—original draft preparation, L.M.; writing-review and editing, E.S. and K.L.; supervision, E.S.; project administration, E.S.; funding acquisition, E.S. All authors have read and agreed to the published version of the manuscript.

Funding: This research was funded by the European Regional Development Fund-Project "Centre for the investigation of synthesis and transformation of nutritional substances in the food chain in interaction with potentially harmful substances of anthropogenic origin: comprehensive assessment of soil contamination risks for the quality of agricultural products" (No. CZ.02.1.01/0.0/0.0/16_019/ 0000845), and by the project of the Ministry of Agriculture of the Czech Republic No. MZeRO0718. 
Institutional Review Board Statement: Not applicable.

Data Availability Statement: The data presented in this study are available within the review.

Conflicts of Interest: The authors declare no conflict of interest. The funders had no role in the design of the study; in the collection, analyses or interpretation of data; in the writing of the manuscript, or in the decision to publish the results.

\section{References}

1. Grice, E.A.; Segre, J.A. The skin microbiome. Nat. Rev. Microbiol. 2011, 9, 244-253. [CrossRef] [PubMed]

2. Montagna, W.; Parakkal, P.F. The Structure and Function of Skin, 3rd ed.; Elsevier: London, UK, 1974; Volume 3, pp. 1-17.

3. Roth, R.R.; James, W.D. Microbial ecology of the skin. Annu. Rev. Microbiol. 1988, 42, 441-464. [CrossRef] [PubMed]

4. Lemieux-Labonté, V.; Tromas, N.; Shapiro, B.J.; Lapointe, F.-J. Environment and host species shape the skin microbiome of captive neotropical bats. Peer J. 2016, 4. [CrossRef] [PubMed]

5. Zeynalova, S.; Asadov, K.; Guliyev, F.; Vatani, M.; Aliyev, V. Epizootology and molecular diagnosis of lumpy skin disease among livestock in Azerbaijan. Front. Microbiol. 2016, 7. [CrossRef] [PubMed]

6. $\quad$ Cogen, A.L.; Yamasaki, K.; Sanchez, K.M.; Dorschner, R.A.; Lai, Y.; MacLeod, D.T.; Torpey, J.W.; Otto, M.; Nizet, V.; Kim, J.E.; et al. Selective antimicrobial action is provided by phenol-soluble modulins derived from Staphylococcus epidermidis, a normal resident of the skin. J. Investig. Dermatol. 2010, 130, 192-200. [CrossRef]

7. Belden, L.K.; Harris, R.N. Infectious diseases in wildlife: The community ecology context. Front. Ecol. Environ. 2007, 5, 533-539. [CrossRef]

8. Hoffmann, A.R.; Patterson, A.P.; Diesel, A.; Lawhon, S.D.; Ly, H.J.; Stephenson, C.E.; Mansell, J.; Steiner, J.M.; Dowd, S.E.; Olivry, T.; et al. The skin microbiome in healthy and allergic dogs. PLoS ONE 2014, 9. [CrossRef]

9. Ross, A.A. The Mammalian Skin Microbiome. Master's Thesis, University of Waterloo, Waterloo, ON, Canada, 23 August 2018.

10. Grice, E.A.; Kong, H.H.; Renaud, G.; Young, A.C.; Bouffard, G.G.; Blakesley, R.W.; Wolfsberg, T.G.; Turner, M.L.; Segre, J.A. A diversity profile of the human skin microbiota. Genome Res. 2008, 18, 1043-1050. [CrossRef]

11. Grice, E.A.; Kong, H.H.; Conlan, S.; Deming, C.B.; Davis, J.; Young, A.C.; Bouffard, G.G.; Blakesley, R.W.; Murray, P.R.; Green, E.D.; et al. Topographical and temporal diversity of the human skin microbiome. Science 2009, 324, 1190-1192. [CrossRef] [PubMed]

12. Capone, K.A.; Dowd, S.E.; Stamatas, G.N.; Nikolovski, J. Diversity of the human skin microbiome early in life. J. Investig. Dermatol. 2011, 131, 2026-2032. [CrossRef] [PubMed]

13. Dey, A.; Nooruddin, M. Economic impact of leather defects in Bangladesh. J. Train. Dev. 1993, 6, 27-38.

14. Foster, A.P. Staphylococcal skin disease in livestock. Vet. Dermatol. 2012, 23, 342-351. [CrossRef]

15. Abrahamian, F.M.; Goldstein, E.J. Microbiology of animal bite wound infections. Clin. Microbiol. Rev. 2011, 24, 231-246. [CrossRef]

16. Costerton, J.W.; Stewart, P.S.; Greenberg, E.P. Bacterial biofilms: A common cause of persistent infections. Science 1999, 284, 1318-1322. [CrossRef] [PubMed]

17. Limoli, D.H.; Jones, C.J.; Wozniak, D.J. Bacterial extracellular polysaccharides in biofilm formation and function. Microb. Biofilms 2015, 223-247. [CrossRef]

18. Meyle, E.; Stroh, P.; Günther, F.; Hoppy-Tichy, T.; Wagner, C.; Hänsch, G.M. Destruction of bacterial biofilms by polymorphonuclear neutrophils: Relative contribution of phagocytosis, DNA release, and degranulation. Int. J. Artif. Organs 2010, 33, 608-620. [CrossRef] [PubMed]

19. Haaber, J.; Penadés, J.R.; Ingmer, H. Transfer of antibiotic resistance in Staphylococcus aureus. Trends Microbiol. 2017, 25, 893-905. [CrossRef] [PubMed]

20. Yang, Q.; Wang, R.; Ren, S.; Szoboszlay, M.; Moe, L.A. Practical survey on antibiotic-resistant bacterial communities in livestock manure and manure-amended soil. J. Environ. Sci. Health 2016, 51, 14-23. [CrossRef]

21. Voss, A.; Loeffen, F.; Bakker, J.; Klaassen, C.; Wulf, M. Methicillin-resistant Staphylococcus aureus in pig farming. Emerg. Infect. Dis. 2005, 11, 1965-1966. [CrossRef]

22. Van Cleef, B.; van Benthem, B.; Verkade, E.J.; van Rijen, M.; Kluytmans-van den Bergh, M.; Graveland, H.; Bosch, T.; Verstappen, K.M.; Wagenaar, J.A.; Bos, M.E.; et al. Livestock-associated MRSA in household members of pig farmers: Transmission and dynamics of carriage, a prospective cohort study. PLoS ONE 2015, 10. [CrossRef]

23. Verkade, E.; Kluytmans-van den Bergh, M.; van Benthem, B.; van Cleef, B.; van Rijen, M.; Bosch, T.; Schouls, L.; Kluytmans, J. Transmission of methicillin-resistant Staphylococcus aureus CC398 from livestock veterinarians to their household members. PLoS ONE 2014, 9. [CrossRef]

24. Cuny, C.; Wieler, L.H.; Witte, W. Livestock-associated MRSA: The impact on humans. Antibiotics 2015, 4, 521-543. [CrossRef]

25. Garcia-Alvarez, L.; Dawson, S.; Cookson, B.; Hawkey, P. Working across the veterinary and human health sectors. J. Antimicrob. Chemother. 2012, 67, 37-49. [CrossRef]

26. Paterson, G.K.; Harrison, E.M.; Holmes, M.A. The emergence of mecC methicillin-resistant Staphylococcus aureus. Trends Microbiol. 2014, 22, 42-47. [CrossRef]

27. Dhup, V.; Kearns, A.M.; Pichon, B.; Foster, H.A. First report of identification of livestock-associated MRSA ST9 in retail meat in England. Epidemiol. Infect. 2015, 143, 2989-2992. [CrossRef] [PubMed] 
28. Sharma, M.; Nunez-Garcia, J.; Kearns, A.M.; Doumith, M.; Butaye, P.R.; Argudín, M.A.; Lahuerta-Marin, A.; Pichon, B.; AbuOun, M.; Rogers, J.; et al. Livestock-associated methicillin resistant Staphylococcus aureus (LA-MRSA) clonal complex (CC) 398 isolated from UK animals belong to European lineages. Front. Microbiol. 2016, 7. [CrossRef] [PubMed]

29. Wellington, E.M.H.; Boxall, A.B.A.; Cross, P.; Feil, E.J.; Gaze, W.H.; Hawkey, P.M.; Johnson-Rollings, A.S.; Jones, D.L.; Lee, N.M.; Otten, W.; et al. The role of the natural environment in the emergence of antibiotic resistance in Gram-negative bacteria. Lancet Infect. Dis. 2013, 13, 155-165. [CrossRef]

30. Lowy, F.D. Staphylococcus aureus infections. N. Engl. J. Med. 1988, 339, 520-532. [CrossRef]

31. Graveland, H.; Duim, B.; van Duijkeren, E.; Heederik, D.; Wagenaar, J.A. Livestock-associated methicillin-resistant Staphylococcus aureus in animals and humans. Int. J. Med Microbiol. 2011, 301, 630-634. [CrossRef] [PubMed]

32. Daaloul-Jedidi, M.; Soudani, A.; Messadi, L. Nasal and rectal carriage of coagulase positive Staphylococcus in healthy goats. J. New Sci. 2016, 33, 1910-1913.

33. Van Cleef, B.A.; Monnet, D.L.; Voss, A.; Krziwanek, K.; Allerberger, F.; Struelens, M.; Zemlickova, H.; Skov, R.L.; Vuopio-Varkila, J.; Cuny, C.; et al. Livestock-associated methicillin-resistant Staphylococcus aureus in humans, Europe. Emerg. Infect. Dis. 2011, 17. [CrossRef]

34. Grace, D.; Fetsch, A. Staphylococcus aureus-A foodborne pathogen: Epidemiology, detection, characterization, prevention, and control: An overview. In Staphylococcus Aureus; Academic Press: Cambridge, MA, USA, 2018; pp. 3-8. [CrossRef]

35. Cuny, C.; Friedrich, A.; Kozytska, S.; Layer, F.; Nübel, U.; Ohlsen, K.; Strommenger, B.; Walther, B.; Wieler, L.; Witte, W. Emergence of methicillin-resistant Staphylococcus aureus (MRSA) in different animal species. Int. J. Med Microbiol. 2010, 300, 109-117. [CrossRef] [PubMed]

36. Smith, T.H.; Fox, L.K.; Middleton, J.R. Outbreak of mastitis caused by one strain of Staphylococcus aureus in a closed dairy herd. J. Am. Vet. Med Assoc. 1998, 212, 553-556. [PubMed]

37. Peton, V.; Le Loir, Y. Staphylococcus aureus in veterinary medicine. Infect. Genet. Evol. 2014, 21, 602-615. [CrossRef] [PubMed]

38. Vanderhaeghen, W.; Hermans, K.; Haesebrouck, F.; Butaye, P. Methicillin-resistant Staphylococcus aureus (MRSA) in food production animals. Epidemiol. Infect. 2010, 138, 606-625. [CrossRef]

39. Acton, D.; Plat-Sinnige, M.J.T.; van Wamel, W.; de Groot, N.; van Belkum, A. Intestinal carriage of Staphylococcus aureus: How does its frequency compare with that of nasal carriage and what is its clinical impact? Eur. J. Clin. Microbiol. Infect. Dis. 2009, 28, 115-127. [CrossRef]

40. Erskine, R.; Cullor, J.; Schaellibaum, M.; Yancey, B.; Zecconi, A. Bovine mastitis pathogens and trends in resistance to antibacterial drugs. In National Mastitis Council Research Committee Report, Proceedings of the Annual Meeting, Charlotte, NC, USA, 1 January 2004; NMC Research Committee: New Prague, MN, USA, 2004.

41. Todhunter, D.A.; Smith, K.L.; Hogan, J.S. Environmental streptococcal intramammary infections of the bovine mammary gland. J. Dairy Sci. 1995, 78, 2366-2374. [CrossRef]

42. Calvinho, L.; Tirante, L. Prevalencia de Microorganismos Patógenos de Mastitis Bovina y Evolución del Estado de Salud de la Glándula Mamaria en Argentina en los Ultimos 25 Años. FAVE Sección Cienc. Vet. 2005, 4. [CrossRef]

43. Davies, P.L.; Leigh, J.A.; Bradley, A.J.; Archer, S.C.; Emes, R.D.; Green, M.J. Molecular Epidemiology of Streptococcus uberis clinical mastitis in dairy herds: Strain heterogeneity and transmission. J. Clin. Microbiol. 2016, 54, 68-74. [CrossRef]

44. Ginn, P.; Mansell, L.; Rakich, P. Jubb, Kennedy, and Palmer's Pathology of Domestic Animals, 5th ed.; Elsevier: Oxford, UK, 2007; pp. 553-781.

45. Cooper, J.E. Veterinary Aspects of Captive Birds of Prey; Standfast Press: London, UK, 1973; pp. 1-256.

46. Van Boeckel, T.P.; Brower, C.; Gilbert, M.; Grenfell, B.T.; Levin, S.A.; Robinson, T.P.; Teillant, A.; Laxminarayan, R. Global trends in antimicrobial use in food animals. Proc. Natl. Acad. Sci. USA 2015, 112, 5649-5654. [CrossRef]

47. Chang, Q.; Wang, W.; Regev-Yochay, G.; Lipsitch, M.; Hanage, W.P. Antibiotics in agriculture and the risk to human health: How worried should we be? Evol. Appl. 2015, 8, 240-247. [CrossRef]

48. Sales of Veterinary Antimicrobial Agents in 31 European Countries in 2020. Available online: https://www.ema.europa.eu/en/ documents / report/sales-veterinary-antimicrobial-agents-31-european-countries-2018-trends-2010-2018-tenth-esvac-report_ en.pdf (accessed on 3 March 2021).

49. Johnson, A.P. Methicillin-resistant Staphylococcus aureus: The European landscape. J. Antimicrob. Chemother. 2011, 66, 43-48. [CrossRef]

50. Michalova, E.; Schlegelova, J. Tetracyclines in veterinary medicine and bacterial resistance to them. Vet. Med. 2004, 49, 79. [CrossRef]

51. Page, S.; Gautier, P. Use of antimicrobial agents in livestock. Rev. Sci. Tech. OIE 2012, 31, 145. [CrossRef]

52. Apley, M.D.; Coetzee, J.F. Antimicrobial Therapy in Veterinary Medicine, 5th ed.; Wiley-Blackwell: Hoboken, NJ, USA, 2013; pp. 495-518.

53. Rayner, C.; Munckhof, W. Antibiotics currently used in the treatment of infections caused by Staphylococcus aureus. Intern. Med. J. 2005, 35, 3-16. [CrossRef]

54. Clark, D. The changing nature of farm systems research. In Proceedings of the New Zealand Society of Animal Production; New Zealand Society of Animal Production: Hamilton, New Zealand, 2013.

55. World Health Statistics 2014. Available online: https://apps.who.int/iris/bitstream/handle/10665/112738/9789240692671_eng. pdf;jsessionid=B3BF04A1EE2E2AA0E05283475C89FE45? sequence=1 (accessed on 24 March 2021). 
56. Biswas, S.; Raoult, D.; Rolain, J.M. A bioinformatic approach to understanding antibiotic resistance in intracellular bacteria through whole genome analysis. Int. J. Antimicrob. Agents 2008, 32, 207-220. [CrossRef]

57. D'Costa, V.M.; McGrann, K.M.; Hughes, D.W.; Wright, G.D. Sampling the antibiotic resistome. Science 2006, 311, 374-377. [CrossRef] [PubMed]

58. Blair, J.M.; Webber, M.A.; Baylay, A.J.; Ogbolu, D.O.; Piddock, L.J.V. Molecular mechanisms of antibiotic resistance. Nat. Rev. Microbiol. 2015, 13, 42-51. [CrossRef] [PubMed]

59. Rammelkamp, C.H.; Maxon, T. Resistance of Staphylococcus aureus to the action of penicillin. Exp. Biol. Med. 1942, 51, 386-389. [CrossRef]

60. Andam, C.P.; Fournier, G.P.; Gogarten, J.P. Multilevel populations and the evolution of antibiotic resistance through horizontal gene transfer. FEMS Microbiol. Rev. 2011, 35, 756-767. [CrossRef] [PubMed]

61. van Hoek, A.H.; Mevius, D.; Guerra, B.; Mullany, P.; Roberts, A.P.; Henk, J.M. Acquired antibiotic resistance genes: An overview. Front. Microbiol. 2011, 203. [CrossRef]

62. Lindsay, J.A. Genomic variation and evolution of Staphylococcus aureus. Int. J. Med Microbiol. 2010, 300, 98-103. [CrossRef] [PubMed]

63. Craft, K.M.; Nguyen, J.M.; Berg, L.J.; Townsend, S.D. Methicillin-resistant Staphylococcus aureus (MRSA): Antibiotic-resistance and the biofilm phenotype. MedChemComm 2019, 10, 1231-1241. [CrossRef] [PubMed]

64. Scherr, T.D.; Heim, C.E.; Morrison, J.M.; Kielian, T. Hiding in plain sight: Interplay between staphylococcal biofilms and host immunity. Front. Immunol. 2014, 5. [CrossRef] [PubMed]

65. Singh, R.; Ray, P.; Das, A.; Sharma, M. Penetration of antibiotics through Staphylococcus aureus and Staphylococcus epidermidis biofilms. J. Antimicrob. Chemother. 2010, 65, 1955-1958. [CrossRef]

66. De la Fuente-Núnez, C.; Reffuveille, F.; Fernández, L.; Hancock, R.E.W. Bacterial biofilm development as a multicellular adaptation: Antibiotic resistance and new therapeutic strategies. Curr. Opin. Microbiol. 2013, 16, 580-589. [CrossRef] [PubMed]

67. Dortet, L.; Anguel, N.; Fortineau, N.; Richard, C.; Nordmann, P. In vivo acquired daptomycin resistance during treatment of methicillin-resistant Staphylococcus aureus endocarditis. Int. J. Infect. Dis. 2013, 17, 1076-1077. [CrossRef]

68. McGuinness, W.A.; Malachowa, N.; DeLeo, F.R. Vancomycin resistance in Staphylococcus aureus. Yale J. Biol. Med. 2017, 90, $269-281$.

69. Chambers, H.F.; DeLeo, F.R. Waves of resistance: Staphylococcus aureus in the antibiotic era. Nat. Rev. Microbiol. 2009, 7, 629-641. [CrossRef]

70. Appelbaum, P.C. Reduced glycopeptide susceptibility in methicillin-resistant Staphyloccocus aureus (MRSA). Int. J. Antimicrob. Agents 2007, 30, 398-408. [CrossRef]

71. Francia, M.V.; Clewell, D.B. Transfer origins in the conjugative Enterococcus faecalis plasmids pAD1 and pAM373: Identification of the pAD1 nic site, a specific relaxase and a possible TraG-like protein. Mol. Microbiol. 2002, 45, 375-395. [CrossRef]

72. Tenover, F.C.; Biddle, J.W.; Lancaster, M.V. Increasing resistance to vancomycin and other glycopeptides in Staphylococcus aureus. Emerg. Infect. Dis. 2001, 7, 327-332. [CrossRef]

73. De Oliveira, L.P.; Barros, L.S.S.; Silva, V.C.; Cirquiera, M.G. Study of Staphylococcus aureus in raw and pasteurized milk consumed in the Reconcavo area of the State of Bahia, Brazil. J. Food Process. Technol. 2011. [CrossRef]

74. Nöremark, M.; Frössling, J.; Lewerin, S.S. Application of routines that contribute to on-farm biosecurity as reported by Swedish livestock farmers. Transbound. Emerg. Dis. 2010, 57, 225-236. [CrossRef] [PubMed]

75. Gibson, G.R.; Probert, H.M.; Loo, J.V.; Rastall, R.A.; Roberfroid, M.B. Dietary modulation of the human colonic microbiota: Updating the concept of prebiotics. Nutr. Res. Rev. 2004, 17, 259-275. [CrossRef] [PubMed]

76. Bomba, A.; Jonecová, Z.; Koscova, J.; Nemcova, R. The improvement of probiotics efficacy by synergistically acting components of natural origin: A review. Biologia 2006, 61, 729-734. [CrossRef]

77. Lemke, S.L.; Mayura, K.; Reeves, W.R.; Wang, N.; Fickey, C.; Phillips, T.D. Investigation of organophilic montmorillonite clay inclusion in zearalenonecontaminated diets using the mouse uterine weight bioassay. J. Toxicol. Environ. Health 2001, 62, 243-258. [CrossRef] [PubMed]

78. Toghyani, M.; Toghyani, M.; Gheisari, A.; Ghalamkari, G.; Eghbalsaied, S. Evaluation of cinnamon and garlic as antibiotic growth promoter substitutions on performance, immuneresponses, serum biochemical and haematological parameters in broiler chicks. Livest. Sci. 2011, 138, 167-173. [CrossRef]

79. Bretaudeau, L.; Tremblais, K.; Aubrit, F.; Meichenin, M.; Arnaud, I. Good manufacturing practice (GMP) compliance for phage therapy medicinal products. Front. Microbiol. 2020, 11. [CrossRef]

80. Ngassam-Tchamba, C.; Duprez, J.N.; Fergestad, M.; De Visscher, A.; L'Abee-Lund, T.; De Vliegher, S.; Wasteson, Y.; Touzain, F.; Blanchard, Y.; Lavigne, R.; et al. In Vitro and in Vivo assessment of phage therapy against Staphylococcus aureus causing bovine mastitis. J. Glob. Antimicrob. Resist. 2020, 22, 762-770. [CrossRef]

81. Milho, C.; Silva, M.D.; Sillankorva, S.; Harper, D.R. Biofilm applications of bacteriophages. In Bacteriophages; Harper, D.R., Abedon, S.T., Burrowes, B.H., McConville, M.L., Eds.; Springer International Publishing: Cham, Switzerland, $2019 ;$ pp. 1-3.

82. Islam, A.; Takagi, M.; Fukuyama, K.; Komatsu, R.; Albarracin, L.; Nochi, T.; Suda, Y.; Ikeda-Ohtsubo, W.; Rutten, V.; Eden, W.; et al. Transcriptome analysis of the inflammatory responses of bovine mammary epithelial cells: Exploring immunomodulatory target genes for bovine mastitis. Pathogens 2020, 9, 200. [CrossRef]

83. Betts, J.W.; Hornsey, M.; La Ragione, R.M. 2018. Novel antibacterials: Alternatives to traditional antibiotics. Adv. Microb. Physiol. 2018, 73, 123-169. [CrossRef] 
84. Rasoanaivo, P.; Wright, C.W.; Willcox, M.L.; Gilbert, B. Whole plant extracts versus single compounds for the treatment of malaria: Synergy and positive interactions. Malar. J. 2011, 10. [CrossRef] [PubMed]

85. Wagner, H.; Ulrich-Merzenich, G. Synergy research: Approaching a new generation of phytopharmaceuticals. Phytomedicine 2009, 16, 97-110. [CrossRef]

86. Hirt, H.M.; M'Pia, B. Natural Medicine in the Tropics 1: Foundation Text: Tropical Plants as a Source of Health Care: Production Medicines and Cosmetics, 3rd ed.; Anamed: Winnenden, Germany, 2008.

87. Ceasar, L.K.; Cech, N.B. Synergy and antagonism in natural product extracts: When $1+1$ does not equal 2. Nat. Prod. Rep. 2019, 36, 869-888. [CrossRef]

88. Barbosa, F.; Pinto, E.; Kijjoa, A.; Pinto, M.M.; Sousa, E. Targeting antimicrobial drug resistance with marine natural products. Int J. Antimicrob. Agents 2020, 56. [CrossRef] [PubMed]

89. Solecki, R.S. Shanidar IV, a Neanderthal flower burial in northern Iraq. Science 1975, 190, 880-881. [CrossRef]

90. Mahady, G.B. Medicinal plants for the prevention and treatment of bacterial infections. Curr. Pharm. Des. 2005, 11, 2405-2427. [CrossRef]

91. Watzl, B.; Leitzmann, C. Bioaktive Substanzen in Lebensmitteln; Georg Thieme Verlag: New York, NY, USA, 2005 ; pp. 1-254.

92. Kamboh, A.; Arain, M.A.; Mughal, M.J.; Zaman, A.; Arain, Z.M.; Soomro, A.H. Flavonoids: Health promoting phytochemicals for animal production-a review. J. Anim. Health Prod. 2015, 3, 6-13. [CrossRef]

93. Maver, T.; Kurečič, M.; Smrke, D.M.; Kleinschek, K.S.; Maver, U. Herbal Medicine; IntechOpen: London, UK, 2018; pp. 121-150. [CrossRef]

94. Assob, J.C.; Kamga, H.L.; Nsagha, D.S.; Njunda, A.L.; Nde, P.F.; Asongalem, E.A.; Njouendou, A.J.; Sandjon, B.; Penlap, V.B. Antimicrobial and toxicological activities of five medicinal plant species from Cameroon Traditional Medicine. BMC Complementary Altern. Med. 2011, 11, 1-11. [CrossRef]

95. Schmid, K.; Ivemeyer, S.; Vogl, C.; Klarer, F.; Meier, B.; Hamburger, M.; Walkenhorst, M. Traditional use of herbal remedies in livestock by farmers in 3 Swiss cantons (Aargau, Zurich, Schaffhausen). Complementary Med. Res. 2012, 19, 125-136. [CrossRef]

96. Poutaraud, A.; Michelot-Antalik, A.; Plantureux, S. Grasslands: A source of secondary metabolites for livestock health. J. Agric. Food Chem. 2017, 65, 6535-6553. [CrossRef] [PubMed]

97. Hahn, N.I. Are phytoestrogens nature's cure for what ails us? A look at the research. J. Acad. Nutr. Diet. 1998, 98, 974-976. [CrossRef]

98. Bassolé, I.H.N.; Juliani, H.R. Essential oils in combination and their antimicrobial properties. Molecules 2012, 17, $3989-4006$. [CrossRef] [PubMed]

99. Ji, X.; Yang, M.; Or, K.H.; Yim, W.S.; Zuo, Z. Tissue accumulations of toxic Aconitum alkaloids after short-term and long-term oral administrations of clinically used radix Aconiti lateralis preparations in rats. Toxins 2019, 11, 353. [CrossRef]

100. Bush, L.; Fannin, F. Alkaloids. In Tall Fescue for the Twenty-first Century, 3rd ed.; Fribourg, H.A., Hannaway, D.B., West, C.P., Eds.; Agronomy Monographs: Madison, WI, USA, 2009; Volume 53, pp. 229-249.

101. Yang, L.; Stöckigt, J. Trends for diverse production strategies of plant medicinal alkaloids. Nat. Prod. Rep. 2010, 27, 1469-1479. [CrossRef] [PubMed]

102. Cushnie, T.T.; Lamb, A.J. Antimicrobial activity of flavonoids. Int. J. Antimicrob. Agents 2005, 26, 343-356. [CrossRef]

103. Mithöfer, A.; Boland, W. Plant defense against herbivores: Chemical aspects. Annu. Rev. Plant Biol. 2012, 63, 431-450. [CrossRef] [PubMed]

104. Qing, Z.-X.; Huang, J.-L.; Yang, X.-Y.; Liu, J.-H.; Cao, H.-L.; Xiang, F.; Cheng, P.; Zeng, J.-G. Anticancer and reversing multidrug resistance activities of natural isoquinoline alkaloids and their structure-activity relationship. Curr. Med. Chem. 2018, 25, 5088-5114. [CrossRef] [PubMed]

105. Ünsal, Ç.; Özbek, B.; Sariyar, G.; Mat, A. Antimicrobial activity of four annual Papaver species growing in Turkey. Pharm. Biol. 2009, 47, 4-6. [CrossRef]

106. Kostic, D.A.; Mitic, S.S.; Mitić, M.; Zarubica, A.R.; Velickovic, J.M.; Dordevic, A.S.; Randelovic, S.S. Phenolic contents, antioxidant and antimicrobial activity of Papaver rhoeas L. extracts from Southeast Serbia. J. Med. Plants Res. 2010, 4, 1727-1732. [CrossRef]

107. Zuo, G.Y.; Meng, F.Y.; Hao, X.Y.; Zhang, Y.L.; Wang, G.C.; Xu, G.L. Antibacterial alkaloids from Chelidonium majus Linn (Papaveraceae) against clinical isolates of methicillin-resistant Staphylococcus aureus. J. Pharm. Pharm. Sci. 2008, 11, 90-94. [CrossRef]

108. Bhattacharjee, I.; Chatterjee, S.K.; Chandra, G. Isolation and identification of antibacterial components in seed extracts of Argemone mexicana L. (Papaveraceae). Asian Pac. J. Trop. Med. 2010, 3, 547-551. [CrossRef]

109. Kim, M.G.; Lee, S.E.; Yang, J.Y.; Lee, H.S. Antimicrobial potentials of active component Isolated from Citrullus colocynthis fruits and structure-activity relationships of its analogues against foodborne bacteria. J. Sci. Food Agric. 2014, 94, 2529-2533. [CrossRef]

110. Pan, X.; Bligh, S.W.; Smith, E. Quinolone alkaloids from fructus Euodiae show activity against methicillin-resistant Staphylococcus aureus. Phytother. Res. 2014, 28, 305-307. [CrossRef]

111. Houdkova, M.; Rondevaldova, J.; Doskocil, I.; Kokoska, L. Evaluation of antibacterial potential and toxicity of plant volatile compounds using new broth microdilution volatilization method and modified MTT assay. Fitoterapia 2017, 118, 56-62. [CrossRef] [PubMed]

112. Hamoud, R.; Reichling, J.; Wink, M. Synergistic antibacterial activity of the combination of the alkaloid Aanguinarine with EDTA and the antibiotic streptomycin against multidrug resistant bacteria. J. Pharm. Pharmacol. 2015, 67, 264-273. [CrossRef] 
113. Tan, K.K.; Khoo, T.J.; Rajagopal, M.; Wiart, C. Antibacterial alkaloids from Artabotrys crassifolius Hook.f. \& Thomson. Nat. Prod. Res. 2015, 29, 2346-2349. [CrossRef] [PubMed]

114. Rong, Q.; Xu, M.; Dong, Q.; Zhang, Y.; Li, Y.; Ye, G.; Zhao, L. In vitro and In vivo bactericidal activity of Tinospora sagittate (Oliv.) Gagnep. var. craveniana (S.Y.Hu) Lo and its main effective component, palmatine, against porcine Helicobacter Pylori. BMC Complementary Altern. Med. 2016, 16, 331. [CrossRef]

115. Azimi, G.; Hakakian, A.; Ghanadian, M.; Joumaa, A.; Alamian, S. Bioassay-directed isolation of quaternary benzylisoquinolines from Berberis integerrima with bactericidal activity against Brucella abortus. Res. Pharm. Sci. 2018, 13. [CrossRef]

116. Yu, J.; Yin, T.P.; Wang, J.P.; Mei, R.F.; Cai, L.; Ding, Z.T. A new C20-diterpenoid alkaloid from the lateral roots of Aconitum carmichaeli. Nat. Prod. Res. 2017, 31, 228-232. [CrossRef] [PubMed]

117. Clinical and Laboratory Standards Institute. Performance Standards for Antimicrobial Susceptibility Testing: Twenty-Fifth Informational Supplement; CLSI: Wayne, PA, USA, 2015; pp. 1-240.

118. Duffy, C.F.; Power, R.F. Antioxidant and antimicrobial properties of some Chinese plant extracts. Int. J. Antimicrob. Agents 2001, 17, 527-529. [CrossRef]

119. Cushnie, T.T.; Cushnie, B.; Lamb, A.J. Alkaloids: An overview of their antibacterial, antibiotic-enhancing and antivirulence activities. Int. J. Antimicrob. Agents 2014, 44, 377-386. [CrossRef] [PubMed]

120. Iwasa, K.; Nishiyama, Y.; Ichimaru, M.; Moriyasu, M.; Kim, H.S.; Wataya, Y.; Yamori, T.; Takashi, T.; Lee, D.U. Structure-activity relationships of quaternary protoberberine alkaloids having an antimalarial activity. Eur. J. Med. Chem. 1999, 34, 1077-1083. [CrossRef]

121. Tong, N.; Zhang, J.; Chen, Y.; Li, Z.; Luo, Y.; Zuo, H.; Zhao, X. Berberine sensitizes mutliple human cancer cells to the anticancer effects of doxorubicin in vitro. Oncol. Lett. 2012, 3, 1263-1267. [CrossRef]

122. López, T.A.; Bianchini, M.L. Biochemistry ofhemlock (Conium maculatum L.) alkaloids and their acute and chronic toxicity in livestock. A review. Toxicon 1999, 37, 841-865. [CrossRef]

123. Green, B.T.; Lee, S.T.; Gardner, D.R.; Welch, K.D.; Cook, D. Bioactive alkaloids from plants poisonous to livestock in North America. Isr. J. Chem. 2019, 59, 351-359. [CrossRef]

124. Daglia, M. Polyphenols as antimicrobial agents. Curr. Opin. Biotechnol. 2012, 23, 174-181. [CrossRef]

125. Srivastava, J.K.; Gupta, S. Extraction, characterization, stability and biological activity of flavonoids isolated from chamomile flowers. Mol. Cell. Pharmacol. 2009, 1, 138. [CrossRef]

126. Cushnie, T.T.; Lamb, A.J. Recent advances in understanding the antibacterial properties of flavonoids. Int. J. Antimicrob. Agents 2011, 38, 99-107. [CrossRef]

127. Saavedra, M.J.; Borges, A.; Dias, C.; Aires, A.; Bennett, R.N.; Rosa, E.S.; Simões, M. Antimicrobial activity of phenolics and glucosinolate hydrolysis products and their synergy with streptomycin against pathogenic bacteria. Med. Chem. 2010, 6, 174-183. [CrossRef] [PubMed]

128. Nirmal, N.P.; Panichayupakaranant, P. Anti-Propionibacterium acnes assay-guided purification of Brazilin and preparation of Brazilin rich extract from Caesalpinia sappan heartwood. Pharm. Biol. 2014, 52, 1204-1207. [CrossRef] [PubMed]

129. Nirmal, N.P.; Panichayupakaranant, P. Antioxidant, antibacterial, and antiinflammatory activities of standardized Brazilin-rich Caesalpinia sappan extract. Pharm. Biol. 2015, 53, 1339-1343. [CrossRef]

130. Dey, D.; Ray, R.; Hazra, B. Antimicrobial activity of pomegranate fruit constituents against drug-resistant Mycobacterium tuberculosis and Beta-lactamase producing Klebsiella pneumoniae. Pharm. Biol. 2015, 53, 1474-1480. [CrossRef]

131. Shahzad, M.; Millhouse, E.; Culshaw, S.; Edwards, C.A.; Ramage, G.; Combet, E. Selected dietary (poly)phenols inhibit periodontal pathogen growth and biofilm formation. Food Funct. 2015, 6, 719-729. [CrossRef]

132. Yuan, M.; Shi, D.Z.; Wang, T.Y.; Zheng, S.Q.; Liu, L.J.; Sun, Z.X.; Wang, R.F.; Ding, Y. Transformation of trollioside and isoquercetin by human intestinal flora in vitro. Chin. J. Nat. Med. 2016, 14, 220-226. [CrossRef]

133. De Freitas, V.A.; Glories, Y.; Monique, A. Developmental changes of procyanidins in grapes of red Vitis vinifera varieties and their composition in respective wines. Am. J. Enol. Vitic. 2000, 51, 397-403.

134. Ultee, A.; Bennik, M.H.J.; Moezelaar, R. The phenolic hydroxyl group of carvacrol is essential for action against the food-borne pathogen Bacillus cereus. Appl. Environ. Microbiol. 2002, 68, 1561-1568. [CrossRef]

135. Dorman, H.D.; Deans, S.G. Antimicrobial agents from plants: Antibacterial activity of plant volatile oils. J. Appl. Microbiol. 2000, 88, 308-316. [CrossRef]

136. Babu, K.S.; Babu, T.H.; Srinivas, P.V.; Sastry, B.S.; Kishore, K.H.; Murty, U.S.N.; Rao, J.M. Synthesis and in vitro study of novel 7-O-acyl derivatives of Oroxylin A as antibacterial agents. Bioorganic Med. Chem. Lett. 2005, 15, 3953-3956. [CrossRef]

137. Silva, L.N.; Zimmer, K.R.; Macedo, A.J.; Trentin, D.S. Plant natural products targeting bacterial virulence factors. Chem. Rev. 2016, 116, 9162-9236. [CrossRef] [PubMed]

138. Manner, S.; Skogman, M.; Goeres, D.; Vuorela, P.; Fallarero, A. Systematic exploration of natural and synthetic flavonoids for the inhibition of Staphylococcus aureus biofilms. Int. J. Mol. Sci. 2013, 14, 19434-19451. [CrossRef] [PubMed]

139. Slobodníková, L.; Fialová, S.; Hupková, H.; Grančai, D. Rosmarinic acid interaction with planktonic and biofilm Staphylococcus aureus. Nat. Prod. Commun. 2013, 8. [CrossRef]

140. Wallock-Richards, D.J.; Marles-Wright, J.; Clarke, D.J.; Maitra, A.; Dodds, M.; Hanley, B.; Campopiano, D.J. Molecular basis of Streptococcus mutans sortase A inhibition by the flavonoid natural product trans-chalcone. Chem. Commun. 2015, 51, 10483-10485. [CrossRef] 
141. Vikram, A.; Jayaprakasha, G.K.; Jesudhasan, P.R.; Pillai, S.D.; Patil, B.S. Suppression of bacterial cell-cell signalling, biofilm formation and type III secretion system by citrus flavonoids. J. Appl. Microbiol. 2010, 109, 515-527. [CrossRef]

142. Ding, T.; Gu, L.; Liu, X. Influence of steam pressure on chemical changes of heat-treated mongolian pine wood. BioResources 2011, $6,1880-1889$.

143. Lin, R.-D.; Chin, Y.-P.; Hou, W.C.; Lee, M.-H. The effects of antibiotics combined with natural polyphenols against clinical methicillin-resistant Staphylococcus aureus (MRSA). Planta Med. 2008, 74, 840-846. [CrossRef]

144. Hu, Z.-Q.; Zhao, W.H.; Asano, N.; Yoda, Y.; Hara, Y.; Shimamura, T. Epigallocatechin gallate synergistically enhances the activity of carbapenems against methicillin-resistant Staphylococcus aureus. Antimicrob. Agents Chemother. 2002, 46, 558-560. [CrossRef]

145. Fan, P.; Lou, H. Effects of polyphenols from grape seeds on oxidative damage to cellular DNA. Mol. Cell. Biochem. 2004, 267, 67-74. [CrossRef]

146. Ugartondo, V.; Mitjans, M.; Touriño, S.; Torres, J.L. Fractions from grape and pine. Chem. Res. Toxicol. 2007, 20, 1543-1548. [CrossRef]

147. Fu, L.; Xu, X.-R.; Gan, R.-Y.; Zhang, Y.; Xia, E.-Q.; Li, H.-B. Antioxidant capacities and total phenolic contents of 62 fruits. Food Chem. 2011, 129, 345-350. [CrossRef]

148. Scalbert, A. Antimicrobial properties of tannins. Phytochemistry 1991, 30, 3875-3883. [CrossRef]

149. Kang, N.J.; Shin, S.H.; Lee, H.J.; Lee, K.W. Polyphenols as small molecular inhibitors of signaling cascades in carcinogenesis. Pharmacol. Ther. 2011, 130, 310-324. [CrossRef]

150. Buzzini, P.; Arapitsas, P.; Goretti, M.; Branda, E.; Turchetti, B.; Pinelli, P.; Romani, A. Antimicrobial and antiviral activity of hydrolysable tannins. Mini-Rev. Med. Chem. 2008, 8. [CrossRef] [PubMed]

151. McLeod, M. Plant tannins-their role in forage quality. Nutr. Abstr. Rev. 1974, 44, 803-815.

152. Smith, A.H.; Mackie, R.I. Effect of condensed tannins on bacterial diversity and metabolic activity in the rat gastrointestinal tract. Appl. Environ. Microbiol. 2004, 70, 1104-1115. [CrossRef] [PubMed]

153. Chung, K.T.; Lu, Z.; Chou, M. Mechanism of inhibition of tannic acid and related compounds on the growth of intestinal bacteria. Food Chem. Toxicol. 1998, 36, 1053-1060. [CrossRef]

154. Taguri, T.; Tanaka, T.; Kouno, I. Antimicrobial activity of 10 different plant polyphenols against bacteria causing food-borne disease. Biol. Pharm. Bull. 2004, 27, 1965-1969. [CrossRef] [PubMed]

155. Widsten, P.; Cruz, C.D.; Fletcher, G.C.; Pajak, M.A.; McGhie, T.K. Tannins and extracts of fruit byproducts: Antibacterial activity against foodborne bacteria and antioxidant capacity. J. Agric. Food Chem. 2014, 62, 11146-11156. [CrossRef] [PubMed]

156. Xu, Y.; Shi, C.; Wu, Q.; Zheng, Z.; Liu, P.; Li, G.; Peng, X.; Xia, X. Antimicrobial activity of punicalagin against Staphylococcus aureus and its effect on biofilm formation. Foodborne Pathog. Dis. 2017, 14, 282-287. [CrossRef] [PubMed]

157. Salih, E.Y.; Julkunen-Tiitto, R.; Lampi, A.M.; Kanninen, M.; Luukkanen, O.; Sipi, M.; Lehtonen, M.; Vuorela, H.; Fyhrquist, P. Terminalia laxiflora and Terminalia brownii contain a broad spectrum of antimycobacterial compounds including ellagitannins, ellagic acid derivatives, triterpenes, fatty acids and fatty alcohols. J. Ethnopharmacol. 2018, 227, 82-96. [CrossRef]

158. Alejo-Armijo, A.; Glibota, N.; Frías, M.P.; Altarejos, J.; Gálvez, A.; Ortega-Morente, E.; Salido, S. Antimicrobial and antibiofilm activities of procyanidins extracted from laurel wood against a selection of foodborne microorganisms. Int. J. Food Sci. Technol. 2017, 52, 679-686. [CrossRef]

159. Chan, C.L.; Gan, R.Y.; Shah, N.P.; Corke, H. Polyphenols from selected dietary spices and medicinal herbs differentially affect common food-borne pathogenic bacteria and lactic acid bacteria. Food Control 2018, 92, 437-443. [CrossRef]

160. Chung, K.T.; Lu, Z.; Chou, M.W. Growth inhibition of selected food-borne bacteria by tannic acid, propyl gallate and related compounds. Lett. Appl. Microbiol. 1993, 17, 29-32. [CrossRef]

161. Xiao, X.-N.; Wang, F.; Yuan, Y.-T.; Liu, J.; Liu, Y.-Z.; Yi, X. Antibacterial activity and mode of action of dihydromyricetin from Ampelopsis grossedentata leaves against food-borne bacteria. Molecules 2019, 24, 2831. [CrossRef] [PubMed]

162. Hancock, V.; Dahl, M.; Vejborg, R.M.; Klemm, P. Dietary plant components ellagic acid and tannic acid inhibit Escherichia coli biofilm formation. J. Med. Microbiol. 2010, 59, 496-498. [CrossRef] [PubMed]

163. Payne, D.E.; Martin, N.R.; Parzych, K.R.; Rickard, A.H.; Underwood, A.; Boles, B.R. Tannic acid inhibits Staphylococcus aureus surface colonization in an IsaA-dependent manner. Infect. Immun. 2013, 81, 496-504. [CrossRef] [PubMed]

164. Farha, A.K.; Yang, Q.-Q.; Kim, G.; Zhang, D.; Mavumengwana, V.; Habimana, O.; Li, H.-B.; Corke, H.; Gan, R.-Y. Inhibition of multidrug-resistant foodborne Staphylococcus aureus biofilms by a natural terpenoid (+)-nootkatone and related molecular mechanism. Food Control 2020, 112. [CrossRef]

165. Lesschaeve, I.; Noble, A.C. Polyphenols: Factors influencing their sensory properties and their effects on food and beverage preferences. Am. J. Clin. Nutr. 2005, 81, 330-335. [CrossRef]

166. Hagerman, A.E.; Riedl, K.M.; Jones, G.A.; Sovik, K.N.; Ritchard, N.T.; Hartzfeld, P.W.; Riechel, T.L. High molecular weight plant polyphenolics (tannins) as biological antioxidants. J. Agric. Food Chem. 1998, 46, 1887-1892. [CrossRef]

167. Pisseri, F.; Bertoli, A.; Pistelli, L. Essential oils in medicine: Principles of therapy. Parassitologia 2008, 50, 89-91. [CrossRef]

168. Dhifi, W.; Bellili, S.; Jazi, S.; Bahloul, N.; Mnif, W. Essential oils' chemical characterization and investigation of some biological activities: A critical review. Medicines 2016, 3, 25. [CrossRef]

169. Lambert, R.; Skandamis, P.N.; Coote, P.J.; Nychas, G.J. A study of the minimum inhibitory concentration and mode of action of oregano essential oil, thymol and carvacrol. J. Appl. Microbiol. 2001, 91, 453-462. [CrossRef] [PubMed] 
170. Baydar, H.; Sagdic, O.; Ozkan, G.; Karadogan, T. Antibacterial activity and composition of essential oils from Origanum, Thymbra and Satureja species with commercial importance in Turkey. Food Control 2004, 15, 169-172. [CrossRef]

171. Nurdin, E.; Amelia, T.; Makin, M. The effects of herbs on milk yield and milk quality of mastitis dairy cow. J. Indones. Trop. Anim. Agric. 2011, 36, 104-108. [CrossRef]

172. Giannenas, I.; Bonos, E.; Christaki, E.; Florou-Paneri, P.C. Essential oils and their applications in animal nutrition. Med. Aromat. Plants 2013, 2, 1-12. [CrossRef]

173. Seow, Y.X.; Yeo, C.R.; Chung, H.L.; Yuk, H.-G. Plant essential oils as active antimicrobial agents. Crit. Rev. Food Sci. Nutr. 2014, 54, 625-644. [CrossRef]

174. Hyldgaard, M.; Mygind, T.; Meyer, R.L. Essential oils in food preservation: Mode of action, synergies, and interactions with food matrix components. Front. Microbiol. 2012, 3. [CrossRef]

175. Cox, S.; Mann, C.M.; Markham, J.L.; Bell, H.C.; Gustafson, J.E.; Warmington, J.R.; Wyllie, S.G. The mode of antimicrobial action of the essential oil of Melaleuca alternifolia (tea tree oil). J. Appl. Microbiol. 2000, 88, 170-175. [CrossRef]

176. Denyer, S.; Hugo, W. Biocide-induced damage to the bacterial cytoplasmic membrane. In Mechanism of Action of Chemical Biocides; Deyner, S.P., Hugo, W., Eds.; Blackwell Scientific Publications: Oxford, UK, 1991; Volume 27, pp. 171-187.

177. Chauhan, A.K.; Kang, S.C. Thymol disrupts the membrane integrity of Salmonella ser. typhimurium in vitro and recovers infected macrophages from oxidative stress in an ex vivo model. Res. Microbiol. 2014, 165, 559-565. [CrossRef]

178. Hippenstiel, F.; Abdel-Wareth, A.A.A.; Kehraus, S.; Südekum, K.-H. Effects of selected herbs and essential oils, and their active components on feed intake and performance of broilers-a review. Arch. Für Geflügelkunde 2011, 75, $226-234$.

179. Mourey, A.; Canillac, N. Anti-Listeria monocytogenes activity of essential oils components of conifers. Food Control 2002, 13, $289-292$. [CrossRef]

180. Burt, S. Essential oils: Their antibacterial properties and potential applications in foods-A review. Int. J. Food Microbiol. 2004, 94, 223-253. [CrossRef]

181. Edris, A.E. Pharmaceutical and therapeutic potentials of essential oils and their individual volatile constituents: A review. Phytother. Res. 2007, 21, 308-323. [CrossRef]

182. Rosato, A.; Piarulli, M.; Corbo, F.; Muraglia, M.; Carone, A.; Vitali, M.; Vitali, C. In vitro synergistic action of certain combinations of gentamicin and essential oils. Curr. Med. Chem. 2010, 17, 3289-3295. [CrossRef] [PubMed]

183. Langeveld, W.T.; Veldhuizen, E.J.A.; Burt, S.A. Synergy between essential oil components and antibiotics: A review. Crit. Rev. Microbiol. 2014, 40, 76-94. [CrossRef] [PubMed]

184. Horky, P.; Skalickova, S.; Smerkova, K.; Skladanka, J. Essential oils as a feed additives: Pharmacokinetics and potential toxicity in monogastric animals. Animals 2019, 9, 352. [CrossRef] [PubMed]

185. Al-Azem, D.A.; Malik Al-Saadi, S.A.A.; Al-Derawi, K.H. The protective effects of Syzygium aromaticum essential oil extract against methotrexate induced hepatic and renal toxicity in rats. J. Pure Appl. Microbiol. 2019, 13, 505-515. [CrossRef]

186. Fateh, A.H.; Mohamed, Z.; Chik, Z.; Alsalahi, A.; Md Zin, S.R.; Alshawsh, M.A. Prenatal developmental toxicity evaluation of Verbena officinalis during gestation period in female Sprague-Dawley rats. Chem. Biol. Interact. 2019, 304, 28-42. [CrossRef]

187. Muhlemann, J.K.; Klempien, A.; Dudareva, N. Floral volatiles: From biosynthesis to function. Plant Cell Environ. 2014, 37, 1936-1949. [CrossRef]

188. Paduch, R.; Kandefer-Szerszeń, M.; Trytek, M.; Fiedurek, J. Terpenes: Substances useful in human healthcare. Arch. Immunol. Et Ther. Exp. 2007, 55, 315-327. [CrossRef]

189. Harborne, J.B. The chemical basis of plant defense. In Plant Defenses against Mammalian Herbivory; CRC Press: Boca Raton, FL, USA, 1991; pp. 45-59.

190. Dudareva, N.; Klempien, A.; Muhlemann, J.K.; Kaplan, I. Biosynthesis, function and metabolic engineering of plant volatile organic compounds. New Phytol. Found. 2013, 198, 16-32. [CrossRef] [PubMed]

191. Raut, J.S.; Karuppayil, S.M. A status review on the medicinal properties of essential oils. Ind. Crop. Prod. 2014, 62, 250-264. [CrossRef]

192. Singh, B.; Sharma, R.A. Plant terpenes: Defense responses, phylogenetic analysis, regulation and clinical applications. 3 Biotech 2015, 5, 129-151. [CrossRef]

193. Porras, G.; Chassagne, F.; Lyles, J.T.; Marquez, L.; Dettweiler, M.; Salam, A.M.; Samarakoon, T.; Shabih, S.; Farrokhi, D.R.; Quave, C.L. Ethnobotany and the role of plant natural products in antibiotic drug discovery. Chem. Rev. 2020, 121, 3495-3560. [CrossRef] [PubMed]

194. Lopez-Romero, J.C.; Gonzáles-Ríos, H.; Borges, A.; Simões, M. Antibacterial effects and mode of action of selected essential oils components against Escherichia coli and Staphylococcus aureus. Evid. Based Complementary Altern. Med. 2015. [CrossRef]

195. Sparg, S.; Light, M.E.; van Staden, J. Biological activities and distribution of plant saponins. J. Ethnopharmacol. 2004, 94, 219-243. [CrossRef]

196. Carelli, M.; Biazzi, E.; Panara, F.; Tava, A.; Scaramelli, L.; Porceddu, A.; Graham, N.; Odoardi, M.; Piano, E.; Arcioni, S.; et al. Medicago truncatula CYP716A12 is a multifunctional oxidase involved in the biosynthesis of hemolytic saponins. Plant Cell 2011, 23, 3070-3081. [CrossRef]

197. Chaieb, I. Saponins as insecticides: A review. Tunis. J. Plant Prot. 2010, 5, 39-50. 
198. Mbaveng, A.T.; Ndontsa, B.L.; Kuete, V.; Nguekeu, Y.M.M.; Celik, I.; Mbouangouere, R.; Tane, P.; Efferth, T. A naturally occuring triterpene saponin ardisiacrispin B displayed cytotoxic effects in multi-factorial drug resistant cancer cells via ferroptotic and apoptotic cell death. Phytomedicine 2018, 43, 78-85. [CrossRef]

199. Lanzotti, V. Bioactive polar natural compounds from garlic and onions. Phytochem. Rev. 2012, 11, 179-196. [CrossRef]

200. Nabinejad, A. Antibacterial effects of Saponaria officinalis extracts against avian pathogenic Escherichia coli (APEC). Afr. J. Agric. Res. 2013, 8, 2068-2071. [CrossRef]

201. Guil-Guerrero, J.; Ramos, L.; Moreno, C.; Zúñiga-Paredes, J.C.; Carlosama-Yepez, M.; Ruales, P. Antimicrobial activity of plant-food by-products: A review focusing on the tropics. Livest. Sci. 2016, 189, 32-49. [CrossRef]

202. Qin, X.-J.; Sun, D.-J.; Chen, C.X.; Hua, Y.; He, L.; Liu, H.-Y. Steroidal saponins with antimicrobial activity fromstems and leaves of Paris polyphylla var. yunnanensis. Steroids 2012, 77, 1242-1248. [CrossRef] [PubMed]

203. Fouedjou, R.T.; Teponno, R.B.; Quassinti, L.; Bramucci, M.; Petrelli, D.; Vitali, L.A.; Fiorini, D.; Tapondjou, L.A.; Barboni, L. Steroidal saponins from the leaves of Cordyline fruticose (L.) A. Chev. And their cytotoxic and antimicrobial activity. Phytochem. Lett. 2014, 7, 62-68. [CrossRef]

204. Srivastava, G.; Jain, R.; Vyas, N.; Mehta, A.; Kachhwaha, S.; Kotharim, S.L. Antimicrobial activity of the methanolic extract, fractions and isolated compounds from Citrullus colocynthis (L.) Schrad. Int. J. Pharma Bio Sci. 2013, 4, 825-833.

205. Fomogne-Fodjo, M.C.; Ndinteh, D.T.; Olivier, D.K.; Kempgens, P.; van Vuuren, S.; Krause, R.W. Secondary metabolites from Tetracera potatoria stem bark with anti-mycobacterial activity. J. Ethnopharmacol. 2017, 195, 238-245. [CrossRef]

206. Tiam, E.R.; Ngono Bikobo, D.S.; Abouem, A.Z.A.; MbabiNyemeck, N.; Moni Ndedi, E.D.F.; Betote Diboue, P.H.; Nyegue, M.A.; Atchade, A.T.; Emmanuel Pegnyemb, D.; Bochet, C.G.; et al. Secondary metabolites from Triclisia gilletii (De Wild) staner (Menispermaceae) with antimycobacterial activity against Mycobacterium tuberculosis. Nat. Prod. Res. 2019, 33, 642-650. [CrossRef] [PubMed]

207. Saboora, A.; Sajjadi, S.-T.; Mohammadi, P.; Fallahi, Z. Antibacterial activity of different composition of aglycone and glycosidic saponins from tuber of Cyclamen coum Miller. Ind. Crop. Prod. 2019, 140. [CrossRef]

208. Korchowiec, B.; Gorczyca, M.; Wojszko, K.; Janikowska, M.; Henry, M.; Rogalska, E. Impact of two different saponins on the organization of model lipid membranes. Biochim. Biophys. Acta (BBA) Biomembr. 2015, 1848, 1963-1973. [CrossRef]

209. Avato, P.; Bucci, R.; Tava, A.; Vitali, C.; Rosato, A.; Bialy, Z.; Jurzysta, M. Antimicrobial activity of saponins from Medicago sp.: Structure-activity relationship. Phytother. Res. Int. J. Devoted Pharmacol. Toxicol. Eval. Nat. Prod. Deriv. 2006, $20,454-457$. [CrossRef]

210. Khan, A.A.; Naqvi, T.S.; Naqvi, M.S. Identification of phytosaponins as novel biodynamic agents: An updated overview. Asian J Exp. Biol. Sci. 2012, 3, 459-467.

211. Martins, A.; Andrea, V.; Viveiros, M.; Molnar, J.; Hohmann, J.; Amaral, L. Antibacterial properties of compounds isolated from Carpobrotus edulis. Int. J. Antimicrob. Agents 2011, 37, 438-444. [CrossRef]

212. Grudniak, A.M.; Kurek, A.; Szarlak, J.; Woslak, K. Oleanolic and ursolic acids influence affect the expression of the cysteine regulon and the stress response in Escherichia coli. Curr. Microbiol. 2011, 62, 1331-1336. [CrossRef] [PubMed]

213. Kurek, A.; Grudniak, A.M.; Szwed, M.; Klicka, A.; Samluk, L.; Wolska, K.; Janiszowska, W.; Popowska, M. Oleanolic acid and ursolic acid affect peptidoglycan metabolism in Listeria monocytogenes. Antonie Van Leeuwenhoek 2010, 97, 61-68. [CrossRef] [PubMed]

214. Ablat, A.; Mohamad, J.; Awang, K.; Shilpi, J.A.; Arya, A. Evaluation of antidiabetic and antioxidant properties of Brucea javanica seed. Sci. World J. 2014, 1. [CrossRef]

215. Coleman, J.J.; Okoli, I.; Tegos, G.P.; Holson, E.B.; Wagner, F.F.; Hamblin, M.R.; Mylonakis, E. Characterization of plant-derived saponin natural products against Candida albicans. ACS Chem. Biol. 2010, 5, 321-332. [CrossRef]

216. Tamokou, J.; Mbaveng, A.T.; Kuete, V. Antimicrobial activities of African medicinal spices and vegetables. Med. Spices Veg. Afr. 2017, 207-237. [CrossRef]

217. Tagousop, C.N.; Tamokou, J.-. de-D.; Kengne, I.Ch.; Ngnokam, D.; Voutquenne-Nazabadioko, L. Antimicrobial activities of saponins from Melanthera elliptica and their synergistic effects with antibiotics against pathogenic phenotypes. Chem. Cent. J. 2018, 12, 1-9. [CrossRef]

218. Yoshikawa, M.; Morikawa, T.; Nakamura, S.; Li, N.; Li, X.; Matsuda, H. Bioactive saponins and glycosides. XXV. Acylated oleanane- type triterpene saponins from the seeds of tea plant (Camellia sinensis). Chem. Pharm. Bull. 2007, 55, 57-63. [CrossRef]

219. Poojary, M.M.; Putnik, P.; Kovačević, D.B.; Barba, F.J.; Lorenzo, J.M.; Dias, D.A.; Shpigelman, A. Stability and extraction of bioactive sulfur compounds from Allium genus processed by traditional and innovative technologies. J. Food Compos. Anal. 2017, 61, 28-39. [CrossRef]

220. Stoewsand, G. Bioactive organosulfur phytochemicals in Brassica oleracea vegetables-A review. Food Chem. Toxicol. 1995, 33, 537-543. [CrossRef]

221. Sagdic, O.; Tornuk, F. Antimicrobial properties of organosulfur compounds. In Dietary Phytochemicals and Microbes; Patra, A.K., Ed.; Springer: Dordrecht, The Netherlands, 2012; pp. 127-156. [CrossRef]

222. Borlinghaus, J.; Albrecht, F.; Gruhlke, M.C.H.; Neachukwu, I.D.; Slusarenko, A.J. Allicin: Chemistry and biological properties. Molecules 2014, 19, 12591-12618. [CrossRef] [PubMed]

223. Cavallito, C.J.; Bailey, J.H. Allicin, the antibacterial principle of Allium sativum. I. Isolation, physical properties and antibacterial action. J. Am. Chem. Soc. 1944, 66, 1950-1951. [CrossRef] 
224. Leontiev, R.; Hohaus, N.; Gruhlke, M.C.H.; Slusarenko, A.J. A comparison of the antibacterial and antifungal activities of thiosulfinate analogues of allicin. Sci. Rep. 2018, 8, 1-19. [CrossRef] [PubMed]

225. Du, L.; Halkier, B.A. Biosynthesis of glucosinolates in the developing silique walls and seeds of Sinapis alba. Phytochemistry 1998, 48, 1145-1150. [CrossRef]

226. Brabban, A.; Edwards, C. The effects of glucosinolates and their hydrolysis products on microbial growth. J. Appl. Bacteriol. 1995, 79, 171-177. [CrossRef]

227. Marchese, A.; Barbieri, R.; Sanches-Silva, A.; Daglia, M. Antifungal and antibacterial activities of allicin: A review. Trends Food Sci. Technol. 2016, 52. [CrossRef]

228. Salehi, B.; Zucca, P.; Orhan, I.E.; Azzini, E.; Adetunji, C.O.; Mohammed, S.A.; Banerjee, S.K.; Sharopov, F.; Rigano, D.; Sharifi-Rad, J.; et al. Allicin and health: A comprehensive review. Trends Food Sci. Technol. 2019, 86, 502-516. [CrossRef]

229. Shaikh, H.; Shaikh, S. Phytochemistry and neuroprotective effect of Alium sativum: An exhaustive review. World J. Adv. Sci. Res. 2020, 3, 155-168.

230. Wallock-Richards, D.; Doherty, C.J.; Doherty, L.; Clarke, D.J.; Place, M.; Govan, J.R.; Campopiano, D.J. Garlic revisited: Antimicrobial activity of allicin-containing garlic extracts against Burkholderia cepacian complex. PLoS ONE 2014, 9. [CrossRef]

231. Hameed, H.M.A.; Islam, M.M.; Chhotaray, C.; Wang, C.; Liu, Y.; Tan, Y.; Li, X.; Tan, S.; Delorme, V.; Yew, W.W.; et al. Molecular targets related drug resistance mechanisms in MDR-, XDR-, and TDR-Mycobacterium tuberculosis strains. Front. Cell. Infect. Microbiol. 2018, 8. [CrossRef] [PubMed]

232. Sorlozano-Puerto, A.; Albertuz-Crespo, M.; Lopez-Machado, I.; Ariza-Romero, J.J.; Banos-Arjona, A.; Exposito-Ruiz, M.; GutierrezFernandez, J. In vitro antibacterial activity of propyl-propane-thiosulfinate and propyl-propane-thiosulfonate derived from Allium spp. against gram-negative and gram-positive multi-drug-resistant bacteria isolated from human samples. BioMed Res. Int. 2018. [CrossRef]

233. Da Cruz, R.C.; Denardi, L.B.; Mossmann, N.J.; Piana, M.; Alves, S.H.; de Campos, M.M. Antimicrobial activity and chromatographic analysis of extracts from Tropaeolum pentaphyllum Lam. tubers. Molecules 2016, 21, 566. [CrossRef] [PubMed]

234. Fujisawa, H.; Watanabe, K.; Suma, K.; Origuchi, K.; Matsufuji, H.; Seki, T.; Ariga, T. Antibacterial potential of garlic-derived allicin and its cancellation by sulfhydryl compounds. Biosci. Biotechnol. Biochem. 2009, 73, 1948-1955. [CrossRef] [PubMed]

235. Kim, J.W.; Huh, J.E.; Kyung, S.H.; Kyung, K.H. Antimicrobial activity of alk (en) yl sulfides found in essential oils of garlic and onion. Food Sci. Biotechnol. 2004, 13, 235-239.

236. Lanzotti, V.; Scala, F.; Bonanomi, G. Compounds from Allium species with cytotoxic and antimicrobial activity. Phytochem. Rev. 2014, 13, 769-791. [CrossRef]

237. Feldberg, R.; Chang, S.; Kotik, A.; Nadler, M.; Neuwirth, Z.; Sundstrom, D.; Thompson, N. In vitro mechanism of inhibition of bacterial cell growth by allicin. Antimicrob. Agents Chemother. 1988, 32, 1763-1768. [CrossRef]

238. Tsao, R.; Peterson, C.J.; Coats, J.R. Glucosinolate breakdown products as insect fumigants and their effect on carbon dioxide emission of insects. BMC Ecol. 2002, 2, 1-7. [CrossRef]

239. Choo, S.; Chin, V.K.; Wong, E.H.; Madhavan, P.; Tay, S.T.; Yong, P.V.C.; Chong, P.P. Review: Antimicrobial properties of allicin used alone or in combination with other medications. Folia Microbiol. 2020, 65, 451-465. [CrossRef]

240. Cai, Y.; Wang, R.; Pei, F.; Liang, B.-B. Antibacterial activity of allicin alone and in combination with $\beta$-lactams against Staphylococcus spp. and Pseudomonas Aeruginosa. J. Antibiot. 2007, 60, 335-338. [CrossRef]

241. Tajima, H.; Kimoto, H.; Taketo, A. Specific antimicrobial synergism of synthetic hydroxy isothiocyanates with aminoglycoside antibiotics. Biosci. Biotechnol. Biochem. 2001, 65, 1886-1888. [CrossRef]

242. Tajima, H.; Kimoto, H.; Taketo, A. Paradoxical effect of synthetic hydroxy isothiocyanates on antimicrobial action of aminoglycosides. Biosci. Biotechnol. Biochem. 2003, 67, 1844-1846. [CrossRef]

243. Banerjee, S.K.; Mukherjee, P.K.; Maulik, S.K. Garlic as an antioxidant: The good, the bad and the ugly. Phytother. Res. 2003, 17, 97-106. [CrossRef]

244. Alnaqeeb, M.A.; Thomson, M.; Bordia, T.; Ali, M. Histopathological effects of garlic on liver and lung of rats. Toxicol. Lett. 1996, 85, 157-164. [CrossRef]

245. McGaw, L.J.; Eloff, J.N. Ethnoveterinary use of southern African plants and scientific evaluation of their medicinal properties. J. Ethnopharmacol. 2008, 119, 559-574. [CrossRef]

246. Hamadani, A.; Ganai, N.A.; Shanaz, S.; Khan, N.; Bukhari, S.S.; Iqbal, Z.; Ayaz, A. Usage of phytochemicals in veterinary practice. J. Entomol. Zool. Stud. 2018, 6, 1997-2000.

247. Ökmen, G.; Cantekin, Z.; Alam, M.I.; Türkcan, O.; Ergün, Y. Antibacterial and antioxidant activities of Liquidambar orientalis Mill. various extracts against bacterial pathogens causing mastitis. Turk. J. Agric. 2017, 5, 883. [CrossRef]

248. Disler, M.; Schmid, K.; Ivemeyer, S.; Hamburger, M.; Walkenhorst, M. Traditional homemade herbal remedies used by farmers of northern Switzerland to treat skin alterations and wounds in livestock. Planta Med. 2013, 79. [CrossRef]

249. Bartha, S.G.; Quave, C.L.; Balogh, L.; Papp, N. Ethnoveterinary practices of Covasna County, Transylvania, Romania. J. Ethnobiol. Ethnomedicine 2015, 11. [CrossRef]

250. Chusri, S.; Tongrod, S.; Saising, J.; Mordmuang, A.; Limsuwan, S.; Sanpinit, S.; Voravuthikunchai, S.P. Antibacterial and antibiofilm effects of polyherbal formula and its constituents against coagulase-negative -positive staphylococci isolated from bovine mastitis. J. Appl. Anim. Res. 2017, 45, 364-372. [CrossRef] 
251. Bruschi, P.; Urso, V.; Solazzo, D.; Tonini, M.; Signorini, M.A. Traditional knowledge on ethno-veterinary and fodder plants in South Angola: An ethnobotanic field survey in Mopane woodlands in Bibala, Namibe province. J. Agric. Environ. Int. Dev. 2017, 111, 105-121. [CrossRef]

252. Kalayou, S.; Haileselassie, M.; Gebre-egziabher, G.; Tiku’e, T.; Sahle, S.; Taddele, G.H.; Ghezu, M. In-vitro antimicrobial activity screening of some ethnoveterinary medicinal plants traditionally used against mastitis, wound and gastrointestinal tract complication in Tigray Region, Ethiopia. Asian Pac. J. Trop. Biomed. 2012, 2, 516-522. [CrossRef]

253. Pattanayak, S.; Dutta, M.K.; Debnath, P.K.; Bandyopadhyay, S.K.; Saha, B.; Maity, D. A study on ethno-medicinal use of some commonly available plants for wound healing and related activities in three southern districts of West Bengal, India. Explor. Anim. Med Res. 2012, 2, 97-110.

254. Mishra, D. Cattle wounds and ethnoveterinary medicine: A study in Polasara block, Ganjam district, Orissa, India. Indian J. Tradit. Knowl. 2013, 12, 62-65.

255. Parthiban, R.; Vijayakumar, S.; Prabhu, S.; Gnanaselvam, E.; Yabesh, M. Quantitative traditional knowledge of medicinal plants used to treat livestock diseases from Kudavasal taluk of Thiruvarur district, Tamil Nadu, India. Rev. Bras. Farmacogn. 2015, 26, 109-121. [CrossRef]

256. Mubarack, H.M.; Doss, A.; Dhanabalan, R.; Venkataswamy, R. Activity of some selected medicinal plant extracts against bovine mastitis pathogens. J. Anim. Vet. Adv. 2011, 10, 738-741. [CrossRef]

257. Tamilselvan, N.; Thirumalai, T.; Elumalai, E.K.; Balaji, R.; David, E. Pharmacognosy of Coccinia grandis: A review. Asian Pac. J. Trop. Biomed. 2011, 1, 299-302. [CrossRef]

258. Migliato, K.F.; Chiosini, M.A.; Mendonca, F.A.; Esquisatto, M.A.; Salgado, H.R.; Santos, G.M. Effect of glycolic extract of Dillenia indica L. combined with microcurrent stimulation on experimental lesions in Wistar Rats. Wounds: A Compend. Clin. Res. Pract. 2011, 23, 111-120.

259. Wenbin, L.; Kandhare, A.D.; Mukherjee, A.A.; Bodhankar, S.L. Hesperidin, a plant flavonoid accelerated the cutaneous wound healing in streptozotocin-induced diabetic rats: Role of TGF- $\beta$ /Smads and Ang-1/Tie-2 signaling pathways. Excli J. 2018, 17, 399-419. [CrossRef]

260. Chakraborty, T.; Gupta, S.; Nair, A.; Chauhan, S.; Saini, V. Wound healing potential of insulin-loaded nanoemulsion with Aloe vera gel in diabetic rats. J. Drug Deliv. Sci. Technol. 2021, 64. [CrossRef]

261. Oryan, A.; Alemzadeh, E.; Eskandari, M.H. Kefir accelerates burn wound healing through inducing fibroblast cell migration in vitro and modulating the expression of IL-1 $\beta$, TGF- $\beta 1$, and bFGF. Probiotics Antimicrob. Proteins 2018, 11, 874-886. [CrossRef] [PubMed]

262. Marcelline, A.N.; Timothée, O.A.; Martial, S.V.; Aminata, A.O.; Armand, K.A.; Claude, K.A.L. In vivo antistaphylococcal activity evaluation of Ocimum gratissimum Linn. (Lamiaceae) ophthalmic ointment. J. Adv. Med. Med Res. 2020, 44-57. [CrossRef]

263. Hase, P.; Digraskar, S.; Ravikanth, K.; Dandale, M.; Maini, S. Management of subclinical mastitis with mastilep gel and herbal spray (AV/AMS/15). Int. J. Pharm. Pharmacol. 2013, 2, 64-67.

264. Abboud, M.; Rammouz, R.; Jammal, B.; Sleiman, M. In vitro and in vivo antimicrobial activity of two essential oils Thymus vulgaris and Lavandula angustifolia against bovine Staphylococcus and Streptococcus mastitis pathogen. Middle East J. Agric. 2015, 4, 975-983.

265. Cho, B.-W.; Cha, C.N.; Lee, S.-O.; Kim, M.-J.; Park, J.-Y.; Yoo, C.Y.; Son, S.-E.; Kim, S.; Lee, H.-J. Therapeutic effect of oregano essential oil on subclinical bovine mastitis caused by Staphylococcus aureus and Escherichia coli. Korean J. Vet. Res. 2015, 55, 253-257. [CrossRef]

266. Kebede, B.; Negese, T. Evaluation of acaricidal effect of ethnoveterinary medicinal plant by in vivo and in vitro against Sarcoptes scabiei var. caprae of infected goats in North Shoa, Oromia regional state, Ethiopia. J. Tradit. Med. Clin. Naturop. 2017, 6. [CrossRef] 